\title{
FUNDAMENTOS DE FISCALIZAÇÃO E ORIENTAÇÃO DO PODER FAMILIAR
}

\author{
Antonio Jorge Pereira Júnior \\ Mestre em Direito Civil pela Faculdade de Direito da \\ Universidade de São Paulo
}

\begin{abstract}
Resumo
O artigo dedica-se ao estudo da natureza juridica do poder familiar (pátrio poder) e de quatro princípios que fundamentam e orientam a interferência da sociedade civil e do Estado em sua administração: cooperação, subsidiariedade, prioridade absoluta da criança e do adolescente, autonomia familiar.
\end{abstract}

Abstract

The article devotes to the study of the juridic nature of the family power (paternal power) and four principles that found and orientate the civil society's and State's interference interference in their administration: principles of cooperation, subsidiariety, absolutely priority of the child and youth and familiar self-government.

Unitermos: poder familiar; fiscalização; fundamentos e princípios.

1. Aspectos sócio-juridicos: natureza jurídica e conteúdo do poder familiar:

\subsection{Noção de poder familiar.}

O poder familiar - conforme denominação do Código Civil de 2002, doravante "CC" - é instituto que legitima a interferência na vida do indivíduo em "peculiar condição de pessoa em desenvolvimento" CF, art. $227, \S 3^{\circ}$ inciso V. Pode ser entendido como síntese de poderes e deveres que possibilitam a condução dos atos e da vida da pessoa absoluta ou relativamente incapaz por defeito de idade (criança e adolescente, nos termos do Estatuto da Criança e do Adolescente, doravante "ECA" Lei Federal 8.069, de 13 de julho de 1990), tendo em vista prepará-la para o exercício pleno da liberdade, fato que se consuma, de ordinário, quando se atinge a maioridade e o indivíduo passa a gozar de plena capacidade de exercício.

Definir a essência do poder familiar é tarefa árdua e dificilmente poderá se dar por concluída algum dia. Como primeira atitude para compreender a relação desse instituto com a família, a sociedade civil e o Estado, é necessário perguntar-se a respeito de sua natureza jurídica, visando à fixação das notas principais do conceito do poder familiar. A partir dessa investigação, pode-se estudar melhor o exercício e os limites do poder familiar, bem como o papel da sociedade e do Estado nesse mister. 
1.2. Dificuldade de se conceituar cientificamente temas de Direito de Família.

Há uma complexidade peculiar ao estudo dos temas ligados à família por se tratar do primeiro e principal círculo social onde a pessoa se torna alvo de variados processos de adaptação social. Esses processos adaptativos' se operam "dentro de sistemas relativamente fechados, que são os circulos sociais, uns envolventes, outros internos, uns que permanecem, outros que passam. A familia é círculo interior permanente" (grifos no original). ${ }^{2}$ No seio familiar se apresentam os diversos processos adaptativos que incidem sobre a personalidade humana. Tais mecanismos também se encontram no macrocosmo da sociedade civil, todavia de forma menos intensiva que na esfera doméstica, como regra.

Enquanto cientista social, Pontes de Miranda diz que "outra lei sociológica, geral, e que por vezes, no trato dos problemas juridicos, se tem de aludir, é a lei de crescente dilatação e integração dos círculos sociais, quando se acham eles em evolução"3 . A crescente interdependência do círculo familiar com relação aos demais círculos, amplia a complexidade do estudo dos institutos júrídicos de Direito de Família. Em matéria de Direito das Crianças e dos Adolescentes, por exemplo, é muito tênue a linha divisória entre o que é matéria de Direito Público e o que é de Direito Privado.

O elevado grau de complexid das relações familiares tem servido de justificativa para o tratamento de certos assuntos do Direito de Família à revelia da Teoria Geral do Direito. Apesar da insuficiência da Teoria Geral do Direito para descrever o fenômeno jusfamiliar, convém esforçar-se para usá-la ao máximo, uma vez que, até o presente, tem-se mostrado como instrumento extremamente útil para a elaboração de um raciocinio jurídico claro e de uma ciência jurídica universal.

\subsection{Natureza jurídica do poder familiar.}

Perguntar-se sobre a natureza jurídica do poder familiar leva antes de tudo ao questionamento do que se compreende por natureza jurídica. Cómo não se trata do objeto específico desse trabalho, entende-se ser suficiente adotar a concepção de José Oliveira Ascensão. ${ }^{4}$

Natureza, filosoficamente, é conceito referido à essência de um ser, de modo que o estudo da natureza juridica deveria levar ao estudo do significado último

I. Há pelo menos sete processos adaptativos identificados por Pontes de Miranda: o religioso, o moral, o cstético, o gnoscológico (ciência), o politico, o juridico c o cconômico (alćm da cducação, da moda ctc).

2. Pontes de Miranda, Tratado de direito privado, $2^{\mathrm{a}} \mathrm{ed}$. , tomo VII, Rio de Janciro, Borsoi, 1955, pp. 163-164.

3. Idem, p. 165.

4. Josć de Olivcira Ascensão, "Naturcza Juridica", Enciclopédia Saraiva de Direito. LIMONGI FRANÇA, Rubens (Coord.). São Paulo, Saraiva, 1980, vol. 54, pp. 95-96. 
dos institutos jurídicos. Esse enfoque é levado a termo na Filosofia do Direito. Quando os demais ramos da Ciência Jurídica se perguntam sobre a natureza jurídica de determinado instituto, pretendem identificar, no âmbito da dogmática, a categoria jurídica na qual melhor ele se insere. Essa determinação pode ser feita após a análise dos seus efeitos jurídicos e, uma vez fixada, deverá exprimir sinteticamente o regime positivamente estabelecido para o instituto. ${ }^{5}$

A reflexão a respeito do poder familiar divide autores entre as categorias de direito subjetivo, ${ }^{6}$ poder-dever ${ }^{7}$ (poder funcional) e situação jurídica. ${ }^{8}$

Obras monográficas costumam apresentar os diferentes conceitos do instituto, ${ }^{9}$ apesar de poucas desenvolverem satisfatoriamente o estudo de sua natureza jurídica. Exatamente por isso não será exposto aqui um repertório de conceituações, para não reincidir em caminho largamente trilhado. Este trabalho se limitará, nesta primeira parte, ao comentário de algumas concepções de autores avalizados em Teoria Geral do Direito Privado para a análise da natureza juridica do poder familiar.

\subsubsection{Conceito de direito subjetivo e natureza jurídica do poder familiar.}

Carlos Alberto da Mota Pinto define o direito subjetivo como "poder jurídico (reconhecido pela ordem juridica a uma pessoa) de livremente exigir ou pretender de outrem um comportamento positivo (ação) ou negativo (omissão) ou de por um ato livre de vontade, só de per si ou integrado por um ato de uma autoridade pública, produzir determinados efeitos jurídicos que inevitavelmente se impõem a outra pessoa (contraparte ou adversário)". ${ }^{10}$

Manuel A. Domingues de Andrade entende o direito subjetivo como poder conferido pela ordem jurídica para tutela de um interesse do próprio titular. ${ }^{\prime \prime}$

\section{Idem, p. 95.}

6. Josć Antonio de Paula Santos Neto entende que o poder familiar é dircito subjetivo c poder funcional, ao mesmo tempo. Disscrtação (Mcstrado cm Dircito), Faculdade de Dircito da Universidade de São Paulo, publicada sob o título Do pátrio poder, São Paulo, Rcvista dos Tribunais, 1994. Manifcsta idêntica opinião Roberto João Elias cm Pátrio poder, guarda de filhos e direito de visita, São Paulo, Saraiva, 1999, p. 9.

7. A maior parte dos autores ć partidário desta concepção. Por todos, scrão citados neste trabalho alguns autores de prestigio $\mathrm{cm}$ matéria de teoria geral do dircito privado: Manucl A. Domingues de Andrade c Carlos Alberto da Mota Pinto, de Portugal; Louis Josscrand, da França; Antonio Cicu c Giuscppe Lumia, da Itália.

8. Antuncs Varcla, Dircito da familia, Lisboa, Petrony, 1996, vol. I, pp. 166 ss.

9. Podem ser consultadas, para csse cfcito: Josć Antonio de Paula dos Santos Neto, Do pátrio podler (cf. cit. 6) e Robcrto Joào Elias, Pátrio poder, guarda de filhos e direito de visita (cf. cit. 6).

10. Carlos Albcrto da Mota Pinto, Teoria geral do direito civil, $3^{4} \mathrm{~cd}$., $5^{4}$ rcimpr., Coimbra, Coimbra Editora, 1991, p. 169.

11. Manucl A. Domingues de Andrade, Teoria geral da relação juridica, Coimbra, Almedina, 1966, vol. I, p. 10, texto c nota. 
Ambos têm em comum a compreensão de que o direito subjetivo pressupõe a possibilidade de livre exercício isto é, sem que exista qualquer dever de exercitá-lo de um poder do qual se é titular. Em função desse ponto de vista, negam que o poder familiar seja direito subjetivo. ${ }^{12}$

José Antonio de Paula Santos Neto rejeita a concepção segundo a qual o direito subjetivo tem por característica essencial a sua livre disponibilidade pelo titular. ${ }^{13}$. Ao conceituar o direito subjetivo segue o ensinamento de Rubens Limongi França, que entendia tal conceito como "o conjunto de faculdades relativas aos direitos conferidos pelas normas (facultates agendi)" 14 A partir da definição,de Limongi França, afirma que o poder familiar teria natureza jurídica de "poder-dever instrumental em face dos filhos e direito subjetivo perante terceiros". 15

Nessa assertiva, Santos Neto faz uma construção equívoca, pretendendo transmitir, a um só passo, efeitos diferentes decorrentes do poder familiar. A rigor, a natureza jurídica diz com a essência do instituto, que é excludente: ou se é essencialmente $A$, ou $B$, ou nem $A$ e nem $B$, mas não $A$ e $B$.

É preferível dizer que se trata de uma natureza jurídica sui generis a dizer que possui duas naturezas. Concluir que não há uma categoria apropriada a um dado instituto é postura necessária quando se constata que sua realidade supera os conceitos até então existentes. Mas, falar em dupla natureza jurídica leva ao contrasenso de afirmar que uma determinada entidade tem duas essências: não é admissível do ponto de vista lógico-filosófico. O princípio da não-contradição impede que uma coisa seja algo e não o seja ao mesmo tempo, sob um mesmo aspecto (neste caso, sob, o aspecto de sua natureza). Não é possível atribuir a um instituto a natureza de direito subjetivo e de poder funcional, ao mesmo tempo, pois tais conceitos de se excluem mutuamente, como se verá adiante.

\subsubsection{Poder funcional e o poder familiar}

dever).

Há muito tempo afirma-se que o poder familiar é poder funcional (poder-

Para Antonio Cicu, o poder familiar é antes de tudo e, sobretudo, um dever dos pais cujo adimplemento se perfaz pelo comportamento deles no exercício da guarda dos filhos. ${ }^{16}$ Também Josserand afirma que o poder paternal (autoridade parental

12. Carlos Albcrto da Mota Pinto, op. cit (cit. 10), p.170; Manuel A. Domingucs de Andrade, op. cit (cit. 11), p. 10 .

13. Josć Antonio de Paula Santos Neto, op. cit (cit.6), p. 60.

14. Rubens Limongi França, Manual de direito civil, 4* cd, São Paulo, Rcvista dos Tribunais, 1980, p. 137.

15. Josć Antonio de Paula Santos Neto, op. cit. (cit.6), p.60.

16. Antonio Cicu, La filiazione, 2" cd., 3*tir., Torino, UTET, p. 351. 
na França de hoje) tem natureza de poder-dever. ${ }^{17}$ Carlos Alberto da Mota Pinto e Manuel A. Domingues de Andrade entendem que o poder familiar tem natureza jurídica de poder funcional. ${ }^{18}$

Convém contrastar brevemente os conceitos de poder funcional e de direito subjetivo. O estudo analítico de Giuseppe Lumia, ${ }^{19}$ acerca da estrutura da relação jurídica, permite uma diferenciação clara da estrutura do poder funcional com relação ao direito subjetivo.

1.3. Contraste entre os conceitos de poder funcional e de direito subjetivo.

Fragmentando a realidade para compreendê-la melhor, Lumia analisa a relação jurídica em cada um de seus elementos - sujeitos, pólos e partes, posições jurídicas subjetivas. Para o estudo comparativo das duas categorias examinadas, será de grande valia a compreensão das "posições juridicas elementares" ("situazioni giuridiche", no original) descritas por ele. A partir da percepção e identificação dessas posições jurídicas subjetivas elementares, a distinção entre o direito subjetivo e o poder funcional ficará mais clara.

Lumia descreve oito posições juridicas elementares ${ }^{20}$ ("o lugar que cada um dos sujeitos ocupa no contexto da relação juridica"), apresentando-as aos pares, seguindo o esquema proposto por W. N. Hohfeld, entre as partes da relação jurídica. Cada posição implica um modo de estar de um sujeito perante o outro sob um determinado aspecto na relação que entre eles se estabelece. Os pares conceituais são, do ponto de vista ativo e passivo, respectivamente: pretensão e dever de comportamento; faculdade e falta de pretensão (derivados de normas de comportamento, também

17. Louis Jossçand, Cours de droit civil positif français, $3^{3}$ cd., Paris, Sircy, 1963, tomol, p. 590.

18. Carlos Alberto da Mota Pinto, op. cit (cit. 10), p. 170; Manucl A. Domingues de Andrade, op. cit. (cit. 11) p. 10, texto e nota.

19. Giuscppc Lumia, Lineamenti di teoria e ideologia del diritlo, $3^{\text {A }} \mathrm{cd}$., Milano, Giuffrc̀, 1981, pp. 102-123. Trecho traduzido ao português, adaptado c modificado por Alcides Tomasctti Jr., nomcado "Teoria da relação juridica", cm abril de 1999, à disposição dos alunos de graduação da Faculdade de Dircito da Universidade de São Paulo. Nestc trabalho, optou-sc pcla utilização da versão do texto de Giuscppc Lumia, claborada por Alcides Tomasctti Jr., professor da Faculdade de Dircito da Universidade de São Paulo, que verteu o italiano "situazione giuridica" $\mathrm{cm}$ posição juridica subjetiva, no português, quando referido à posição $\mathrm{cm}$ que o sujcito sc coloca perantc outro, $\mathrm{cm}$ uma mesma relação jurídica, modificando c adaptando à doutrina brasilcira as idćias expostas. Quando Lumia se refere ao quadro geral constituido pela relação jurídica, também fala cm "situazione giuridica" Neste caso, Alcides Tomasetti traduziu como situação juridica, no português. Visando facilitar a lcitura no original, foi trazido, cm rodapé, o texto correspondente às citações mais importantes.

20. Alcides Tomasctti Jr., "Tcoria da rclação jurídica", tradução, modificação c adaptação do capitulo "raporto giuridico", da obra de Giuscppe LUMIA, Lineamenti di teoria e ideologia del dirillo, $3^{2}$ cd., Milano, Giuffrè, 1981, p. 102-123. À disposição dos alunos de graduação da Faculdadc de Dircito da Universidade de São Paulo. São Paulo, 1999, pp. 07-09. Cf.

Giuscppc Lumia, op. cit (cit.19), pp.109-111. 
chamadas normas primárias); imunidade e falta de poder; poder formativo e sujeição (dois últimos pares ligados às normas de competência).

Trabalhando com as combinações desses pares, Lumia observa que o direito subjetivo apresenta-se como "um complexo unitário (e unificante) de posições juridicas subjetivas elementares" 21 "A figura juridica do direito (em sentido) subjetivo responde substancialmente a uma exigência de economia mental; não é mais que uma fórmula abreviada estenográfica, por assim dizer - por intermédio da qual designase uma constelação de posições juridicas subjetivas ativas elementares" 22

Já o poder funcional, ou poder-dever, é poder jurídico (atribuído ou reconhecido como pertencente a um sujeito) vinculado ao dever de exercício desse poder. $\mathrm{O}$ titular do poder funcional fica sujeito a sanções caso não observe $o$ dever que lhe é imputado.

O titular de um direito subjetivo assume apenas e somente posições juridicas subjetivas ativas elementares (faculdade, pretensão, poder formativo, imunidade), que podem se apresentar combinadas de diversas formas, de acordo com o caso concreto.

O resultado da combinação de posições jurídicas subjetivas elementares é chamado por Lumia de "posição juridica subjetiva complexa"

O poder funcional também é uma posição jurídica subjetiva complexa. Todavia, o titular de um poder funcional, à diferença do titular de um direito subjetivo, possui ao lado das posições juridicas subjetivas ativas decorrentes das normas de competência (poder formativo e imunidade) uma posição jurídica subjetiva passiva no âmbito das normas de comportamento (normas primárias).

Por isso Lumia afirma que "dos direitos subjetivos distinguem-se nitidamente os poderes funcionais (potestà, no original), que implicam uma outra $e$ diversa categoria de posição juridica subjetiva complexa. O conceito de poder funcional decorre da conjunção entre um poder formativo e um dever comportamental (obbligo, no original). Realmente, nos poderes funcionais, determinadas posições juridicas são atribuidas a um sujeito para a satisfação de interesses que não são estritamente seus, como, por exemplo, ocorre com o poder funcional conferido ao pai sobre os filhos menores; com os poderes funcionais atribuidos aos órgãos públicos no interesse da coletividade; com os poderes funcionais que caracterizam a atuação dos órgãos das pessoas juridicas, etc. As pessoas investidas nesses poderes não são livres de exercitálos, ou não, de modo que a perseguição daqueles interesses não fica confiada ao mero arbitrio do titular de uma faculdade, mas à prudente discricionariedade vinculada do

21. Alcides Tomasctti Jr., op. cit. (cit. 20), p. 09. Giuscppc Lumia, op. cit. (cit. 19), p. I12. No original: "Il diritto soggettivo si presenta come un complesso unitario (e unificante) di situazione ginridiche elementari."

22. Alcides Tomasetti Jr, op. cit. (cit.20), p. 10. Giuseppe Lumia, op. cit. (cit.19)., p. 113. No original: "la figura giuridica del diritto soggettivo risponde in buona sostanza ad una esigenza di economia mentale: essa è nient'altro che una formula abbrevita, per cosi dire stenografica, con la quale si denota una costellazione di situazioni gituridiche elementari che si presentano abitualmente collegate." 
sujeito investido numa posição juridica ativa, que ele tem o dever de exercitar, no sentido de modificar a situação juridica do sujeito passivo"23

\subsubsection{Conceito de poder em Direito Privado.}

Como comentário final à breve análise do poder funcional, dois argumentos somam ajudam a esclarecer a noção de poder, chamado indistintamente pela doutrina para efeitos de estudo do poder familiar - de poder-dever, poder instrumental ou poder funcional.

Gaillard desenvolve a noção de poder em Direito Privado, chegando à conclusão de que há duas categorias de prerrogativas jurídicas essencialmente diferentes: os direitos subjetivos, que conferem a seu titular plena liberdade de exercício (tendo como limitação ínsita o prejuízo que sua atuação possa causar a terceiros), e os poderes (poderes funcionais, entre os quais está o poder familiar), cujo exercício atende, pelo menos parcialmente, a interesses alheios aos do titular, pelo que, em função disso, torna-se ele passível de controle judiciário, diante da possibilidade de prejuízo a terceiro pelo seu desvio. Afirma, de modo expresso e conclusivo, não ser possível conceber situações mistas de direito subjetivo e poder funcional (como pretendia Santos Neto): "não existem direitos mistos". ${ }^{24}$

Para Roubier, "o poder, na linguagem do direito, é uma prerrogativa que permite a seu titular intervir na esfera juridica de outros; ele permite a uma pessoa levar o governo sobre a pessoa de outro, dar-lhe ordens e diretivas (poder sobre a pessoa), ou ainda permite-lhe administrar os bens de outrem, gerir seus bens de uma maneira mais ou menos ampla (poder sobre os bens). [...], o titular deste poder não deve agir por interesse pessoal, mas no interesse do agrupamento ou da pessoa no nome de quem age" (tradução nossa). ${ }^{25}$

23. Alcides Tomasctti Jr., op. cit. (cit.20), pp. 15-16. Giuscppe Lumia, op. cit. (cit.19), p. 120. No original: "Dai diritti soggetttivi vanno nettamente distinte le potestà. Il concetto di potestà scaturisce dal coniugarsi di un potere con un obbligo. Nella potestà, infatti, determinati potere sono attribuiti al singolo per il soddlisfacimento di interesse che non sono specificamente suoi: tali, per esempio, la potestà conferita ai genitori sui figli minori, l poteri attibuiti agli organi pubblici nell'interesse della collettività, ecc. Ma coloro che sono investiti di una polestà non sono liberi di esercitare o meno i poteri all esse conferiti nell interesse altrui, ma sono obbligati ad esercitarli; e il perseguimento di tali interessi non é afjictato al mero arbitrio del titolare della facoltà, ma alla sua prudente discrezionarità. Colui che è investito di una potestà è quindi titolare di poteri, il cui uso discrezionale costituisce per lui un obbligo: ciò si suole indicare coi termini di ufficio o, più frequentemente, di finzione. Correlativamente alla potestà corrispondono dal lato passivo del potere, una soggezione, e dal lato attivo dell "obbligo, una pretesa".

24. Emmanucl Gaillard, Le pouvoir en droit privé, Paris, Economica, 1985, p. 232.

25. Paul Roubicr, Droits subjectifs et situations juridiques, Paris, Dalloz, 1963, p. 186. No original, citação completa do parágrafo: "Le pouvoir, dans la langue du droit, est tune prérogative qui permet à son titulaire d'empiéter sur la sphère juridique d'autrui; il permet à une personne de prendre le gouvernement de la personne d'un autre, de lui donner des ordres et des directives (pouvoir sur la personne), on encore il permet à une personne de prendre l'administration des biens d'autrui, de gérer ses biens d'une manière 
As teorias acerca do desvio do poder abrangem as situações em que o poder paternal é desviado de sua função, seja por abuso, seja por omissão (CC de 2002 , art. 1.637, caput, que trata dos limites por abuso ou omissão dos deveres paternais). Nesses casos caberá intervenção do Estado e da sociedade na gestão do poder paternal.

\subsection{Poder familiar como situação jurídica.}

Outra possibilidade aventada por alguns juristas, acerca de poder familiar, é a de se tratar de uma situação jurídica. É o entendimento de Antunes Varela. ${ }^{26}$

Todavia, dada a amplidão do conceito de "situação jurídica", que abrange inumeráveis ocorrências em matéria de Direito, esse enfoque não parece ser o mais indicado como delimitador da natureza jurídica do poder familiar.

Autores usam essa terminologia para referir-se a idéias diferentes. Assim, Emilio Betti ${ }^{27}$ compreende "situação jurídica" de um modo diferente de Paul Roubier. Antonio $\mathrm{Cicu}^{28}$ também apresenta entendimento diferente do conceito de "situação jurídica" na explicação do "status" No Brasil, Marcos Bernardes de Mello vale-se da expressão "situação jurídica" para significar o efeito imediato de um fato jurídico, in genere.

Várias dessas concepções de situação jurídica englobam o poder familiar. Mas sob mesma conceituação encontram-se institutos bem diferentes dele, pelo que a inserção do poder familiar na categoria "situação jurídica", apesar de ser possível, não explica, por si só, notas peculiares que o informam geneticamente e podem ser aferidas pela classificação do poder familiar como poder funcional.

1.5. Tutela juridica do exercício do poder familiar.

Quando se pretende definir a natureza jurídica de um instituto, convém fixar-se em suas principais notas características, relegando a um segundo momento

plus ou moins large (pouvoir sur le biens). On verra bientôt que ce qui caractérise le pouvoir par rapport au droit, c'est que le titulaire de ce pouvoir ne doit pas agir pour son intérèt personnel, mais dans l'intérèt du groupement ou de la personne au nom de qui il agit. C"est la rançon obligatoire du pouvoir; on ne peut empiéter sur la sphère juridique d'autrui que dans l'intérèt d'autrui, et non pas dans son propre intérèt."

26. Antunes Varcla, op.cit (cit. 8), p. 166. Segundo Antunes Varcla, citando Gernruber, esse é o entendimento dominante na Alcmanha.

27. Emílio Betti entende que situações juridicas "constitucm respostas que a ordem jurídica dá às diferentes situações de fato que são configuradas à medida que vão sobrevindo os fatos jurídicos". Representam um "modo de estar" jurídico de determinadas situações concretas configuradas pela ordem jurídica após a ocorrência de fatos jurídicos. Scria o retrato da situação estabelecida por um fato juridico. Esse "instantânco" juridico de uma situaçào de fato juridicizada, ć modificado à medida que a situaçìo concreta que subjaz a cla scrve de suporte fático à incidência de outra norma, incidência esta que, por sua $v e z$, constitui um novo fato jurídico, $\mathrm{c}, \operatorname{logo}$, por cfeito cascata surge uma nova situação juridica diferente da anterior (outro "instantânco"). A rclação jurídica, por cxemplo, para Bctti, é uma cspécic de situaçăo juridica. Teoria geral do negócio juridico, Coimbra, Coimbra Editora, 1969, pp.19-20 
aspectos secundários que possam complicar a tarefa de classificação. Os atributos essenciais são levados em conta em detrimento dos acidentais. Por isso é desacertada a postura de quem afirma que o poder familiar tem natureza jurídica de direito subjetivo pela faculdade dada aos pais para reagir em face de quem prejudica o seu exercício, ou pela atribuição de usufruto legal dos bens do filho (CC, art. 1.689, inciso I). O usufruto legal dos bens do filho, por sinal, não interfere na natureza jurídica do poder familiar e não existe na maioria dos ordenamentos.

Dois fundamentos podem servir para a defesa do exercício do poder familiar por quem de direito, sem a necessidade de afirmar que se trata de direito subjetivo dos pais. Um primeiro fundamento decorre da nota de exclusividade do poder familiar, que é o mais imediato. Outro, mais remoto, diz com os direitos fundamentais dos pais, que têm direito de exercitar livremente os poderes jurídicos que receberam, em face dos demais cidadãos.

Pode-se analisar cada um deles em separado.

\subsubsection{Tutela fundada sobre a nota de exclusividade do poder familiar.}

A principal característica do poder familiar, do ponto de vista jurídico, é a prestação de serviços dos pais em relação aos fillhos. Na administração desse poder podem os pais reagir perante ingerência alheia. Isso decorre da nota de exclusividade que acompanha o titular do poder paternal.

Quando essa exclusividade, que se manifesta na liberdade de conduzir os poderes conferidos pelo título, respeitando-se os direitos fundamentais da criança e do adolescente, é turbada, podem os pais reagir.

Esta prerrogativa é assegurada pela lei (CC art. 1.631), mas não chega a se converter em direito subjetivo dos pais, no sentido acima expresso (Lumia), pois compõe o rol de poderes que pertencem aos titulares do poder familiar e ao mesmo tempo são indisponiveis e irrenunciáveis. ${ }^{29}$ Os pais não só não podem renunciar a esse poder de defesa, como respondem pelo mau exercício - a omissão, neste caso - que façam dele.

Nas palavras de Walter Moraes: "O direito atual vê no pátrio poder [poder familiar] liame que impõe aos pais o dever de suprir deficiencias naturais de filhos menores, prestando-lhes a assistência que a sua condição exige. Trata-se de dever, cuja exclusividade de exercício a lei assegura aos pais, oponivel, por conseguinte, como um direito, a terceiros: é o múnus privado, o ministério, o direito-função, direitodever, $o$ poder" (grifos no original). ${ }^{30}$

O título de poder familiar confere poderes-deveres que se exercem, via de regra, com exclusividade, de tal sorte que os titulares podem opor-se a terceiros que

29. Robcrto Joño Elias, Pátrio poder; guarda dos filhos e direito de visita, São Paulo, Saraiva, 1999, p. 30.

30. Walter Moracs, Programa de direito do menor, São Paulo, Cultural Paulista, 1984, p. 189. Convćm notar que o autor não classifica o poder familiar como dircito subjetivo. Estabclece apenas um termo comparativo ao dizer que o poder familiar ć oponivel a terceiros "como um direito". 
pretendam interferir no seu exercício. O atributo exclusividade está a serviço da função do poder, e essa exclusividade responde à necessidade dos filhos de serem administrados por uma única fonte de poder: os titulares do poder familiar.

\subsubsection{Tutela fundada no dever geral de respeito às posições jurídicas.}

Quando se interfere negativamente no exercício legítimo de função que compete a outrem, surge para este, de imediato, o poder jurídico de reação. Em matéria de poder familiar, o fundamento imediato desta reação se encontra na exclusividade que o caracteriza, conforme apresentado.

Também justifica a defesa do titular do poder familiar o fato de ser pessoa. Toda pessoa é titular de direitos fundamentais que são protegidos e garantidos pelo ordenamento jurídico positivo. Esses direitos implicam deveres para todos (erga omnes), correlativos, recíprocos ${ }^{31}$ e genéricos. São irrenunciáveis, juridicamente, mesmo que os titulares destruam os bens tutelados ou não reajam em face de ofensa alheia. ${ }^{32}$

$\mathrm{O}$ art. $5^{\circ}$, inciso II, da CF diz que "ninguém será obrigado a fazer ou deixar de fazer alguma coisa senão em virtude de lei". Os pais não estão obrigados a se sujeitarem a interferências externas no exercício do poder familiar se cumprem seus deveres com relação aos filhos não emancipados. Portanto, podem reagir juridicamente quando ocorre alguma intromissão alheia.

Por essa linha de raciocínio, o poder familiar se aproxima de um direito fundamental dos pais: irrenunciável, indisponivel e defensável erga omnes. Enquanto os titulares respeitam os direitos fundamentais dos que lhes estão sujeitos, todos devem respeitar o livre exercício do poder familiar.

Deve-se recorrer a essa argumentação como ultima ratio, quando não for possivel garantir o livre exercício do poder familiar aos pais por meio da nota de exclusividade.

31. "Com os conceitos de bilateralidade e reciprocidade procura-se acentuar que, das relaçôes jurvidicas nascem poderes [enr sentido amplo] e deveres [em sentido amplo] correlativos, eem duplo sentido: primeiro. que ao poder de um corresponde o dever de outro (e nisto consiste a bilateralidade); segundo: que um sujeito não pode operar de certo modo, relativamente a am outro sujeito, sem com isso legitimar esse illtimo, nas mesmas condiçōes, a um comportamento análogo em face do primeiro stijeito (nisto consiste a reciprocidadc)". Giuscppe Lumia, op. cit. (cit. 19), p. 104. Versão de Alcides Tomaselti Jr., op. cit. (cit.20), p. 2. Colocou-se cntre colchetcs o acréscimo fcito por Tomasctti, com rclação ao original.

32. Apcsar de ser comum ocorrer a adoção de criança com o consentimento dos pais naturais, nem por isso o poder familiar pode scr classificado como dircito subjclivo, renunciável c disponivel, pois o fundamento juridico dessas situações não está na vontade dos pais, mas no interesse da criança. O resultado da adoção, ncstes casos, quando lido às avessas, fez que alguns interpretcm o poder familiar como renunciável e disponível. Trata-se de um crro de perspectiva: olhar para o cfeito do ato c interpretar como causa ć um crro de percepção que distorcc a reta comprecnsão dos fenômenos juridicos. Na rcalidade, ncssas situaçõcs o que ocorre ć a antecipação da proteção que seria outorgada ao menor $\mathrm{cm}$ momento posterior, ao sc comprovar que não existc interesse dos pais naturais ctn excrcitar a função que lhes compctc, ao mesmo tcmpo $\mathrm{cm}$ que outros sc apresentam com tal pretensão. Assim como sc admitc o inadimplemento antecipado, $\mathrm{cm}$ Dircito Obrigacional, aqui, $\mathrm{cm}$ matéria de Dircito da Criança c do Adolescentc, admitc-se a antecipação da perda do título, para constituir novo titular, $\mathrm{cm}$ beneficio do menor. 
Os direitos fundamentais, pela compreensão de Roubier, também adotada neste trabalho, não devem ser confundidos com direitos subjetivos, uma vez que estes seriam indisponiveis enquanto aqueles seriam disponiveis.

\subsection{Distinção entre título e exercício.}

O CC, art. 1.631, e o ECA, art. 21, estabelecem quem pode exercitar, originariamente, o poder familiar: os pais, em igualdade de condições. Gozam ambos de poderes e direitos para exercitar essa função. Todavia, antes de passar ao estudo dos administradores do poder familiar, convém diferenciar os conceitos de título e exercício de poderes juridicos, uma vez que haverá dissociações no poder familiar.

O titular de uma posição jurídica subjetiva ativa costuma possuir direitos e poderes correspondentes ao título que fundamenta sua posição. Geralmente a aquisição de um título importa no aumento de poderes em sua esfera jurídica. Todavia, algumas vezes o título pode reduzir alguns dos poderes que o titular possuía. ${ }^{33}$

Em algumas situações a ordem jurídica permite o desdobramento do título em relação aos poderes que seriam outorgados por ele. É o que ocorre na situação do nu proprietário. Apesar de ter o título de proprietário, os poderes e o respectivo exercício dos mesmos concentram-se nas mãos de outra pessoa (o usufrutuário, por exemplo). Com isso verifica-se a distinção entre aquele que tem o titulo de uma posição jurídica e aquele que exercita os poderes correspondentes a ele.

Habitualmente, quem possui o título está legitimado a agir de acordo com os poderes que ele confere, salvo restrição que o titular aplique a si mesmo, limitação que a lei prescreva ou decisão de autoridade competente que provoque a diminuição de poderes. No caso da nua propriedade, esse efeito se opera por restrição que o proprietário faz aos poderes que o título de domínio lhe outorgava.

Distingue-se, portanto, titulo de exercicio dos poderes conferidos ao titular de uma posição jurídica subjetiva ativa.

Em matéria de poder familiar, essa distinção tem uma série de aplicações práticas, como se verá. ${ }^{34}$

Do ponto da Teoria Geral do Direito, o que justifica essa separação? Qual o ponto de apoio para a cisão entre posição jurídica e exercício dos poderes que a posição atribui? O conceito de legitimidade pode servir de fundamento técnico-jurídico para a separação do título do poder familiar com relação ao exercicio das prerrogativas

33. Veja-se o caso do tutor. Recebe cle um título, de tutor, acompanhado de scus poderes respectivos. $\mathrm{Na}$ cxata medida cm que o título de tutor, ao constituir relaçào juridica deste com a pupila, coloca-a cm uma posição desigual perante cle - pois cla fica-lhe submetida juridicamente -, sofre cle a limitação do impedimento dirimente de contrair matrimônio com a pupila, tendo por finalidade proteger o patrimônio c a idoncidade moral dela (CC, art. I.523, IV). Isso durará cnquanto perdura a tutcla.

34. Caso evidenciado especialmente no CC, art. I.637, que disciplina os casos de suspensão do poder familiar, bem como nos arts. $155 \mathrm{c}$ scguintes do ECA, que abordam os trâmites processuais para a suspensão. 
que ele confere. Todavia, dada a limitação formal deste trabalho, não será possível expor tal estudo neste momento. ${ }^{35}$

1.7 Título e exercício com relação ao poder familiar.

Pelo conceito de legitimação pode-se melhor compreender as situações em que um sujeito é titular de uma posição, mas um outro se encontra legitimado para exercitar os poderes ligados àquele título.

Quando há suspensão do poder familiar, por exemplo, os pais permanecem titulares da posição sem, no entanto, terem legitimidade atual para exercitar os poderes decorrentes dessa posição. $O$ exercício, ligado à legitimidade, passa a outra pessoa (CC, art. 1.637, combinado com o ECA, arts. 24, 129, inciso X e 155 a 163).

O conceito de legitimação se presta a uma dupla função: identificar $o$ sujeito na relação (pelo que se garante o título da posição jurídica) e imputar-lhe um poder configurado ou um vínculo qualificado, fora do qual ele não está legitimado a agir. $^{36}$ Enquanto a titularidade, tal qual entendida tradicionalmente, refere-se a um âmbito estático das relações jurídicas (as posições), a legitimidade se refere à dinâmica das relações, por estar ligada ao exercício das prerrogativas concedidas pelas posições. Da posição jurídica emanam poderes, naturalmente. Mas, pode ser que a lei, a autoridade competente ou a situação criada pelas partes opere a cisão entre exercício e título: a legitimidade é dada a um sujeito diferente daquele que primeiramente ocupava a posição jurídica.

É o que se verifica no caso da guarda concedida a uma pessoa, na hipótese de suspensão do poder familiar. Nesse caso pode-se entender que, do ponto de vista jurídico, por disposição judicial, criou-se uma relação jurídica nova, entre o guardião e o menor de idade. Todavia, o conteúdo dessa relação é "emprestado" da posição jurídica que caberia ao titular do poder familiar, de modo que o titular do poder familiar, sem perder a posição, perde o exercício (em várias de suas prerrogativas), que é atribuído ao guardião. O guardião, por sua vez, acha-se legitimado em função das prerrogativas atribuídas a ele e que outrora pertenciam aos pais. Estes se mantêm na posição de titulares do poder familiar, mas falta-lhes legitimidade para exercer o poder que o título da posição lhes conferiria (estão impedidos).

O titular do poder familiar goza de uma série de poderes que devem ser exercidos em função do bem da pessoa que lhe fica submetida, condenando-se o abuso (CC, art. 1.637). Para a preservação do título e dos poderes respectivos, deve o titular agir em conformidade com a finalidade do próprio título. Quando não age assim, sofre

35. Cf. Antonio Jorge Pcrcira Júnior, Conselho tutelar: fundamentos sócio-juridicos da orientação e fiscalização do poder familiar pela sociedade e pelo Estado. Disscrtaçào de Mestrado, Faculdade de Dircito da Universidade de São Paulo, 2002, pp. 28-36.

36. Torquato Castro, “A Revisão do Código Civil” (1), A propósito da revisão do códligo civil: três conferências, Recife, scparata da Revista Symposium, da Universidade Católica de Pernambuco, ano XIII, n I, I97I, p. 18 
ingerência nos poderes que lhe foram atribuídos, que podem ser reduzidos temporária ou definitivamente (suspensão e perda do poder familiar, respectivamente).

\subsubsection{Distinção e relação entre o título de poder familiar e o título de filiação}

Em paralelo ao título de poder familiar deve ser colocado o título de paternidade. São duas realidades diferentes, ainda que seus efeitos costumem andar emparelhados até o momento da maioridade. Ao mesmo tempo, convém recordar que o título de poder familiar é temporário por natureza, desaparecendo com a maioridade civil (CC, art. 392, II). Difere do título de paternidade/filiação, que se constitui para ser perdurável (independe da idade).

A conservação do título de poder familiar nas mãos dos pais, a quem pertence originariamente, fica condicionada ao exercício adequado dos poderes atribuídos, ou seja, ao uso legítimo desses poderes (sem abuso ou omissão que comprometam o bem dos filhos). O mau exercício do poder familiar pode levar a uma reação judicial que, em último grau, pode culminar na extinção do poder familiar e na colocação do menor em família substituta, sob o regime de adoção. Neste caso, o exercício indevido do poder familiar irromperia o próprio título de filiação.

No Brasil, o poder familiar, como tal, está vinculado à presença dos pais (sejam naturais, sejam adotivos), de modo que desaparece quando estes desaparecem e também quando se opera a perda judicial do poder familiar sem sua reposição. Nessas hipóteses, abre-se espaço para o surgimento das figuras sucedâneas do poder familiar.

Fora do País, todavia, há Estados que permitem a transferência do poder familiar aos avós ${ }^{37}$ e há autores que propugnam pela dissociação do poder familiar com relação à filiação, resultando na possibilidade de terceiros, sem vínculos familiares pré-estabelecidos com os menores, assumirem-no (o título de poder familiar) integralmente, sem a necessidade de mudança no título de filiação, pensando-se no bem-estar da criança ou adolescente ${ }^{38}$

37. No México, por excmplo, na ausĉncia dos pais, os avós patcrnos ou matcrnos (ncsta ordem) assumem o poder familiar integralmente. Cf. Robcrto João Elias, op. cit. (cit.29), p. 22.

38. Anne-Maric Lcroyer propõe a desvinculação do titulo de poder familiar do titulo da filiação, (o quc ocorria no Dircito Romano) defendendo a transferência do poder familiar, com a integralidade dos poderes que costumam acompanhá-lo, a pessoas diferentes dos pais (natural ou juridicamente reconhecidos), tendo cm vista a necessidade de cstabilidade familiar que os incapazes por defeito de idade precisam ter perante àqueles que, ainda não sendo os pais, ocupam a posição originariamente cabível a cles. Quando reccbem apenas o exercicio decorrente da autoridade parental, sofrem uma sćric de limitações que os próprios pais não sofrem, além de corrcrem um risco maior que os próprios pais quanto à alteração da guarda por decisão judicial. A transferçncia do título da autoridade parental, renomeado de autoridade familiar, facilitaria o tratamento c garantiria a cstabilidade no excré́cio dos poderes outorgados, gcrando uma situaçào de segurança conveniente para a criança ou adolescente que se encontram sob a guarda de uma pessoa impedida de adotar (caso da avó, por cxemplo, ou do irmão mais velho). Assim haveria a transferência do título de autoridlade familiar àquele que substitui os pais na condução da vida do menor de idade, dando-lhe maior autonomia para exercer cssa função, que a autonomia mitigada com a simples atribuição de poderes parciais. "L 'énfant confié à un tiers: de l'autorité parentale $\dot{a}$ l'autorité familiale", Revue Trimestrielle de Droit Civil. Paris, juil]-scpt-1998, pp. 587-606. 
1.8. Guarda, tutela civil e tutela administrativa.

No Brasil, o título de poder familiar pertence exclusivamente aos pais, sendo deferido a terceira pessoa o exercício de alguns dos poderes que o integram, por meio de disposição judicial, quando os pais estão impedidos de exercitá-lo (CC, art. 1.637) ou quando perdem o poder familiar (CC, art. 1.638).

A suspensão e a perda do poder familiar não afetam o título de filiação, por si sós, como se disse anteriormente. ${ }^{39}$ A inibição parcial (suspensão) costuma levar à constituição da guarda, em paralelo ao poder familiar. A inibição total (perda) leva à extinção do título e abre caminho para a tutela civil, principal sucedâneo do poder familiar. $^{40}$

Enquanto perdura a incapacidade civil por defeito de idade, deve-se garantir à pessoa o auxílio de quem possa zelar para que os seus direitos sejam respeitados, sob risco de ser prejudicada a formação de sua personalidade.

\subsubsection{A guarda.}

A constituição da guarda é a primeira resposta judicial à situação de criança ou adolescente desatendido pelos pais, segundo un critério de urgência, voltado à regularização da posse de fato do incapaz (ECA, art. $33, \S \S 1^{\circ}$ e $2^{\circ}$, neste último caso coexistindo com o título de poder familiar). "A guarda transfere ao guardião, a título precário, os atributos constantes do art. 1.634, I, II, VI e VII" do CC. ${ }^{41}$ De acordo com o ECA, art. $33, \S$ único, o juiz pode inclusive deferir o direito de representação ao guardião, para a prática de certos atos, o que não era possivel em face da legislação anterior. $^{42}$

\subsubsection{A tutela civil.}

"A tutela, em sentido amplo, é o cuidado levado, sob a inspeção do Estado, por uma pessoa de confiança (o tutor) sobre a pessoa e o patrimônio de quem não está em situação de cuidar de seus assuntos por si mesmo ou que pelo menos é tratado juridicamente como se não estivesse. "43

39. Salvo na hipótese de chegar à colocação da criança cm familia substituta mediante adoção.

40. "O instituto da tutcla civil ć sucedânco do pátrio poder [poder familiar]. Este característico definc a tutcla cm qualquer Icgislação civil moderna” Walter Moracs, op. cit. (cit.30), p. 181.

41. Munir Cury, Jurandir Norberto Marçura c Paulo Afonso Garrido de Paula, Estatıto da criança e do adolescente anotado, $2^{2}$ cd., São Paulo, Revista dos Tribunais, 2000, p. 45.

42. De acordo com o Código de Menores de 1979, arts. 21 a 23, cra possivel a delegação o pátrio poder. Tal delegação criava uma situação diferente da guarda, pois cnquanto o delegado tinha o poder de representar os menores, o guardião não o tinha.

43. Ludwig Enneccrus, Theodor Kipp, Martin Wolff, Tratado de derecho civil. Derecho de familia, $2^{2}$ cd., Barcclona, Bosch, 4"tomo, vol. II, 1979, p. 266. 
Mais completo e estável que a guarda é o instituto da tutela civil, especialmente delineado no ECA, art. 36. De acordo com o art. 36, §único, os poderes do guardião também se integram nas mãos do tutor. A tutela, todavia, confere mais atributos do poder familiar ao tutor que a simples guarda.

Ao mesmo tempo, o tutor goza de menos liberdade que os pais na administração da vida da pessoa sob sua tutela, estando submetido a maior vigilância das autoridades públicas. A diferença entre os graus de liberdade e de poderes dados ao titular do poder familiar e ao tutor pode ser perfeitamente percebida nos dispositivos que descrevem ambas as situações. ${ }^{44}$ Apesar de o art. 1.740 do CC, inciso III, conferir mais poderes ao tutor que aqueles previstos no $\mathrm{CC}$ de 1.916 , continua ele (tutor), com menos poder do que os pais no exercício do poder familiar. A carga fiscalizatória que pesa sobre ele é maior, entre outros motivos, pelo fato de os pais, quando no exercício do poder familiar, contarem com o reforço do título de paternidade. É natural que os pais tenham maior liberdade de ação que o tutor, que age subsidiariamente a eles.

Substituto do poder familiar, a tutela é disciplinada pelo Direito de Família $^{45}$. A matéria está regulada no CC, sobretudo nos arts. 1.728 a 1.766, e no ECA, arts. 36 a 38. Pressupõe a extinção do poder familiar (morte dos pais ou decisão judicial de perda) ou pelo menos a sua suspensão. ${ }^{46}$ Geralmente, constitui-se quando não mais existe o poder familiar, e, excepcionalmente, coexiste com ele nos casos de suspensão. À tutela civil corresponde um título próprio que justifica a posição assumida pelo tutor. O título de tutor é constituído a partir da nomeação ou confirmação judicial (CC, art. 1.732).

Os principais tipos de tutela estão descritos na lei. ${ }^{47}$

44. O art. 1.741 do CC cstabclece que "incumbe ao tutor sob a inspeção do juiz administrar os bens do tutelado em proveito deste, cumprindo seus deveres com zelo e boat-fe" (grifos nossos), o que não sc verifica $\mathrm{cm}$ relação aos pais. $\mathrm{O}$ art. 1.740 , versando sobrc as competências do tutor, conferc-lhe menos poderes que o art. 1.634 aos pais. Algumas compctências do tutor ficam dependentes da "autorização judicial" (CC, art. $1.748 \mathrm{c}$ 1.749). Por fim, o tutor não goza de usufruto legal dos bens do pupilo, bencficio cabivel aos pais, com relação aos filhos, quando no excrcício do poder familiar (CC, art. 1.689, inciso 1). Por outro lado, poderá reccber rcmuncração pclo excrcicio da tutcla (art. 1.734). Para a fiscalização do tutor, por sinal, o $\mathrm{CC}$ de 2002 trouxc a novidade do protutor, que pode ser nomcado pelo juiz para auxiliá-lo nesta função (CC art. 1.742), sendo digno de cventual remuncração a scr fixada pclo magistrado (art. $1.752, \$ 1^{\circ}$ ).

45. Heinrich Lchmann, Derecho de familia. Tratado de derecho civil, Madrid, Revista de Derecho Privado, 1953, vol.4, p. II.

46. Respectivamente: ECA, art. 36, §único; CC, art. 406, II; CC, art. 406, I.

47. Tutela testamentíria, pela qual os pais nomeiam tutor $\mathrm{cm}$ documento ou testamento para o caso de virem a faltar quando ainda cstiver na menoridade o filho (CC, art. 1.729); tutela legitima, pela qual algum parcnte assume o espaço deixado pclos pais, de acordo com uma ordem de convocação (CC, art. I.73I), scmpre que não scja cxista ou não possa scr consumada a tutcla testamentária; tutcelı dativa, pela qual cabc ao juiz designar um tutor, quando não for possivel rcalizar-sc nenhuma das anteriores: não existência de documento que consigne disposição de última vontade dos pais accrea da tutcla ou nomeaçào testamentária de pessoa não idônca para assumir o cncargo, acrescido da impossibilidade de designar tutor pela legítima - por incxistência, cscusa ou inidoncidade dos parentes que poderiam assumi-la (CC, art. 1.732). 


\subsubsection{A tutela administrativa.}

Tão logo se verifique a ausência dos pais, o Estado buscará a quem transferir o exercício dos poderes correspondentes à tutela do incapaz por defeito de idade. Não encontrando a quem delegar a função substitutiva dos pais, alguns autores defendem que deveria o Estado assumi-la, por intermédio da tutela administrativa. ${ }^{48}$ Há quem defenda que, antes mesmo de se constituir juridicamente a tutela civil, por meio da qual se pode dizer que a sociedade assume a responsabilidade pela formação do incapaz por defeito de idade, o Estado, primeira entidade protetora da criança e do adolescente, deveria assumir essa função, em socorro imediato ao menor desamparado. No Brasil, a lei não possui tal previsão.

A tutela administrativa seria provisória, e deveria durar pelo menos até que se conseguisse regularizar a posse de fato de criança ou adolescente, mediante a concessão liminar de guarda, nos processos de tutela civil ou de adoção, ou ainda nos casos de simples concessão de guarda a algum membro da sociedade civil (ECA, art. $33, \S \S 1^{\circ}$ e $2^{\circ}$ ).

Malogradas as tentativas de colocar o menor em família substituta por intermédio da adoção, tutela civil, ou guarda, manteria o Estado a tutela administrativa sobre o menor. Enquanto ela perdurasse, o Estado, representado no Chefe do Executivo municipal, manteria o menor sob sua custódia. Paralelamente, o Judiciário e a Assistência Social do município deveriam buscar quem se dispusesse a assumir a tutela civil ou a guarda do menor. Não se encontrando pessoa interessada em assumir pelo menos a guarda do menor, o Estado consolidaria sua tutela administrativa, que deixaria de ser provisória, mas manteria o caráter precário, na expectativa de alcançar a colocação do menor em família substituta antes de findada a menoridade, pois as demais formas (guarda deferida a quem deseje cuidar do menor ou tutela civil) têm preferência sobre a tutela estatal, por imitar melhor a natureza familiar.

A tutela administrativa, proposta de lege ferenda no Brasil, seria exigida do Estado como conseqüência da primazia que ele tem de zelar pelo amparo e bemestar das crianças e adolescentes.

\subsubsection{A adoção.}

A adoção é meio de colocar o menor em nova família, constituindo-se novo título de filiação. Sendo menor de idade o adotado, os adotantes tornam-se titulares do poder familiar que ressurge com o novo título de filiação.

48. Proposta de lege ferenda, apresentada por Roberto Joào Elias, rccolhida na obra Tutela civil, Sĩo Paulo, Saraiva, 1986, c descnvolvida por Sćrgio Matheuz Garcez, que plcitcava $\mathrm{cm}$ scu trabalho pela previsão cstatutária desse tipo de tutcla, que scria excrcida pelo Estado por meio de órgàos de sua Administração, na falta de pais ou de tutores civis do menor, cm Onovo direito da criança e do adolescente, Campinas, E.V., 1994, p. 63. 


\subsection{Conteúdo mínimo do poder familiar.}

O poder familiar tem conteúdo mínimo que pode ser deduzido da $\mathrm{CF}$, do $\mathrm{CC}$ e, especialmente, do ECA. Neste diploma encontram-se as normas que prevêem as situações em que é cabível a interferência dos órgãos públicos encarregados de proleger o menor. A lei regula essa atuação estatal. ${ }^{49}$

Entre as situações que legitimam a intervenção, destacam-se, primeiramente, as previstas no art. 98 do ECA, inciso II. Este dispositivo fundamenta a interferência quando se constata "falta, omissão ou abuso dos pais ou responsável" prejudicando os direitos dos menores. São situações de inobservância dos limites mínimos (ou seja, deveres) exigidos pela Lei, para o exercício livre do poder funcional.

Quando a conduta dos pais ameaçar ou violar direitos resguardados pelo ECA, legitima-se a intervenção da sociedade civil e do Estado. ${ }^{50}$ A conduta omissiva ou abusiva dos pais com relação aos fillhos implica, necessariamente, desrespeito a algum dos preceitos do poder familiar. Por isso torna-se necessário fazer a conexão entre o conteúdo dos poderes paternais e a intervenção dos agentes incumbidos de proteger a vítima do mau uso do poder lamiliar.

\subsubsection{Conteúdo dos poderes-deveres paternos}

Para esboçar o conteúdo dos poderes-deveres paternos convém apresentar o arcabouço legal onde se concentram. Alguns dos principais dispositivos relativos a essa matéria, podem ser encontrados na CF, art. 229, no CC, art. 1.634 e arts. 1.689 a 1.693, no ECA, arts. 21, 22, 55 e 129, inciso V.

A CF, art. 229, fala dos deveres dos pais de assistir, criar e educar os filhos menores.

$\mathrm{O} \mathrm{CC}$ divide a matéria em poderes-deveres quanto à pessoa dos fillos (art. 1.634) e quanto aos bens dos filhos (arts. 1.689 a 1.693).

$\mathrm{O}$ art. 1.634 dispõe que compete aos pais dirigir a criação e a educação dos fillhos (inciso I), e tê-los em sua guarda e companhia (inciso II). Compete-lhes, ainda, exercitar poderes relacionados à incapacidade de fato dos filhos: conceder ou negar-lhes consentimento para casarem (III); nomear-lhes tutor em certos casos (IV); representá-los ou assisti-los juridicamente, conforme a idade (V); reclamá-los de quem ilegalmente os detenha (VI); exigir deles obediência, respeito e serviços compatíveis com a idade (VII).

Os arts. 1.689 a 1.693 referem-se aos poderes sobre o patrimônio do filho, que interessam secundariamente neste trabalho.

49. Por excmplo, o art. 98 do ECA diz quando cabc intervir, aplicando-se medidas de proteção descritas no art. 101.

50. Vcja-se a respcito: Edson Sêda; $A$ a $Z$ do conselho tutelur, Rio de Janciro, Adès, 1999. No site www.edsonseda.hpg.ig.com.br/anzf.hm, resposti à pergunta n“ 15, paginalçaío variável. Acessado em 1.5/10/200J: 
$\mathrm{O}$ art. 22 do ECA fala de quatro deveres dos pais: sustento, guarda, educação do filho e cumprimento das determinações judiciais.

Analisando os dispositivos citados, percebe-se que não há unidade terminológica entre a CF, o CC e o ECA. A CF, especialmente, apesar de ser diploma jurídico, também é uma carta política, de maneira que os termos utilizados em sua redação nem sempre retratam os temas de Direito com a melhor técnica. Mas, sendo a $\mathrm{CF}$ a chave de interpretação de todo o sistema jurídico nacional, deveria servir como principal referência para a análise dos poderes-deveres que integram o poder familiar.

Dada a conveniência de tomá-la como referência, pode-se notar uma divisão tripartite dos poderes-deveres, enunciados no art. 229: assistir, criar e educar. Qual é o conteúdo desses atos? Qual a distinção entre eles?

Essas condutas (assistir, criar, educar) justificam-se em função da necessidade que toda pessoa, em condição peculiar de desenvolvimento, tem de ser acompanhada por outras, já formadas, que a conduzam à maturidade suficiente para o exercício pleno da liberdade. Como não há unidade terminológica entre a $\mathrm{CF}, \mathrm{CC}$ e ECA, a doutrina qualificada de Walter Moraes, em matéria de direito do menor, pode servir como critério para a organização desses poderes, associando a cada conjunto de deveres, sugeridos por ele, uma das condutas expressas na $\mathrm{CF}$.

Segundo Walter Moraes, os pais devem atender às necessidades dos menores em três âmbitos de assistência, de acordo com as necessidades dos filhos: assistência material (associada ao criar da CF), assistência moral (relacionada ao educar da CF) e a assistência juridica (que pode ser vinculada à expressão assistir da CF).

A assistência material será prestada pelos responsáveis mediante o cumprimento de deveres voltados à satisfação das necessidades físicas da criança ou do adolescente. Desdobra-se nos deveres de criação, sustento e guarda.

Por criação, entende-se o cuidado relacionado ao desenvolvimento físico do menor, incluindo o lazer e a recreação. Numa palavra, o zelo pelo crescimento fisiológico. Esse dever pode ser fundamentado na CF, art. 229 (criar), e no art. 1.634 do CC. O sustento, para Walter Moraes, absorve os deveres relacionados às necessidades alimentares e médicas do menor, ou seja, o zelo pela saúde. Este dever está especialmente previsto nos arts. 231, IV do CC e no ECA, art. 22. A guarda, por seu turno, inclui habitação e vestuário, restando vinculada à proteção fisica, e está delineada pelo Direito Positivo estatal nos arts. 231, IV e 1.634, I do CC, e no ECA, art. 22. ${ }^{51}$

A assistência moral - chamada de assistência pessoal não material será prestada pelos responsáveis e inclui o dever de companhia (CC, art. 1.634, II; ECA, art. 19), pelo qual os pais devem estar próximos do filho dando-lhe a atenção afetiva necessária para que sua constituição emotiva seja segura e equilibrada, e o dever de educação (CF, art. 229, ECA, art. 22), que forja a personalidade do indivíduo nas diversas frentes que compõem a pessoa humana: moral, religiosa, intelectual e profissional (CC, art. 1.566, IV e 1.724; ; 1.634, I; 1.740, I e 1.747, III). 
Uma terceira categoria de serviço se concretiza na assistência jurídica (CF, art. 229, ECA, art. 22, última parte) prestada pelos responsáveis por meio da representação (CC art. 1.634, V), assistência stricto sensu (art. 1.634, V e 1.747, I), consentimento para casamento (art. 1.634, III), nomeação de tutor por testamento ou documento similar (art. 1.634, IV); administração dos bens do menor (CC arts. 1.689 a 1.693 e 1.741); usufruto legal (CC art. 1.689, I).

Tomando por referência a classificação de Walter Moraes e a terminologia constitucional, pode-se colocar os dispositivos citados em uma tabela, de modo a facilitar a associação dos diplomas normativos.

Divisão comum quanto às atribuições do paterfamilias é a que se dá entre os poderes relacionados à pessoa, ${ }^{52}$ e os poderes relacionados aos bens ${ }^{53}$ do filho. Poderes de caráter patrimonial (enquanto administradores dos bens da prole) e pessoal (onde se inclui o dever de zelar pela formação saudável da personalidade do filho).

\begin{tabular}{|l|l|l|}
\hline ASSISTÊNCIA MATERIAL & ASSISTENCIA MORAL & ASSISTÊNCIA JURÍDICA \\
\hline CF, art. 229: criar & CF, art. 229: educar & CF, art. 229: assistir \\
\hline & & - Representação \\
- Criação: crescimento físico & & - Assistência stricto sensu \\
- Sustento: cuidado da saúde & - Companhia & - Consentimento para casar \\
- Guarda: proteção fisica & Educação & - Nomeação de tutor \\
& & - Administração de bens do filho \\
& & - Usufruto legal \\
\hline CC: arts. 1.566, IV; 1.634, I & CC: arts. 1.566, IV; 1.634, I e & CC: arts. 1.634, III, IV, V; 1.689- \\
& II; 1.740, I e 1.747, III & $1.693 ; 1.741 ; 1.747$, I \\
\hline ECA, art. 22 & ECA, art. 19 & ECA, art. 22, última parte \\
\hline
\end{tabular}

Dentre esses poderes, mais importantes que os relacionados à administração dos bens são os que se referem à pessoa do filho. Nestes deveres estão os principais fins do poder familiar, pois serão fundamentais para a formação integral da pessoa. Para confirmar essa hierarquia do ponto de vista do Direito Positivo estatal, pode-se analisar o CC em conjunto com o ECA.

Diz o ECA, art. 22: "aos pais incumbe o dever de sustento, guarda e educação dos filhos menores, cabendo-lhes ainda, no interesse destes, a obrigação de

52. CC, título I: "do direito pessoal"; subtítulo II: "das relações de parentesco"; capítulo V: "do poder familiar"; seção II: "do exercício do poder familiar"

53. CC, título II: "do direito patrimonial"; subtítulo II: "do usufruto e da administração dos bens dos filhos menores" 
cumprir e fazer cumprir as determinações judiciais. " $\mathrm{O}$ artigo seguinte (art. 23) sobreleva eventual dificuldade econômica dos pais. A dificuldade para o sustento material dos filhos não autoriza a mudança do titular do poder familiar. Para estes casos concebeu a lei o "programa de auxilio comunitário" (ECA, art. 101, inciso VI). "A falta ou carência de recursos materiais não constitui motivo suficiente para a perda ou suspensão do pátrio poder [poder familiar]". Ou seja, o principio da autonomia familiar se mantém e o princípio da cooperação vem ao encontro dessa situação, obrigando a sociedade civil e o Estado a socorrerem os pais, sem substituí-los na posição de educadores.

A conduta moral dos pais, portanto, importa mais que sua condição econômica para efeitos de fiscalização do poder familiar.

Quando o filho possui patrimônio próprio, adquirido mediante doação, legado ou herança, por exemplo, cabe aos pais a administração desse montante, como regra. O dever mínimo a ser observado nesses casos é o de conservação do valor representado por esse patrimônio. Caso isso não aconteça, por flagrante desídia dos responsáveis, de modo que se comprometa seriamente o patrimônio (o CC, art. 1.637, fala de arruinar os bens do filho), pode o juiz suspender o poder familiar. Somente a reiteração dessa conduta, que configura sinal de desinteresse pelo bem o filho, pode levar à perda do poder familiar, de acordo com um dispositivo do CC (art. 1.638, IV), sem precedentes no CC de 1916.

Essa conseqüência demonstra que a lei civil reconhece o valor dos direitos patrimoniais do filho sujeito ao poder familiar. Todavia, a falha dos pais nesse plano não se equipara à falta com relação aos direitos do filho de índole pessoal, como sejam os direitos de personalidade, ligados à formação da pessoa.

Quando há ofensa, ou perigo de ofensa, a essa categoria de bens, imateriais, pode-se aplicar o remédio extremo da perda do poder familiar, sem exigência de reiteração dos pais na prática ofensiva (CC, art. 1.638). Assim, em situações de descuido do dever de guarda e educação, pode-se determinar, além da suspensão, de caráter revogável e temporário, a medida da perda do poder familiar. São situações que ensejam esta medida, aquelas descritas no artigo 1.638 do Código Civil: (I) castigar imoderadamente o filho, (II) deixá-lo em abandono e (III) praticar atos contrários à moral e aos bons costumes.

Os três incisos do art. 1.638 descrevem condutas dos pais que põem em risco direitos fundamentais do filho: a vida (I e II) e a formação sadia da personalidade, por meio da educação e da convivência tamiliar (III) e, novidade do CC de 2002, a perda do patrimônio (IV). Ao mesmo tempo, o art. 23 do ECA afasta as medidas acima apontadas - suspensão e perda do poder familiar -, nas situações de carência de recursos materiais, quando tal situação não for imputável aos pais como decorrência de desrespeito aos deveres do poder familiar. Esta regra protege os pais que, a despeito das dificuldades de subsistência material, continuam atuando de modo responsável no cuidado do filho, resguardando seus direitos básicos ou, ao menos, esforçando-se positivamente por fazê-lo. Nestes casos os pais deverão ser assistidos materialmente pela sociedade e pelo Estado. 
A educação e a companhia assumem posição primeira na hierarquia de deveres dos pais e serão o ponto principal de fiscalização, orientação e intervenção de agentes exteriores (sociedade civil e Estado) quando há má gestão do poder familiar pelos responsáveis originários.

1.10 Fiscalização do poder familiar pelo Estado e pela sociedade.

O caráter publicista do Direito de Família deve-se à existência de um interesse social premente na organização familiar. Os poderes exercitados dentro do âmbito familiar têm repercussão social positiva ou negativa, devido à inter-relação entre os círculos sociais.

A família e a sociedade civil organizada são sociedades naturais. ${ }^{54}$ Há semelhança entre os modos de organização dos poderes inerentes a cada uma delas. Assim como a autoridade pública goza de atribuições que devem ser exercitadas no interesse de pessoas diferentes de si, assim também os pais com relação aos fillhos, na administração do poder familiar.

Ao poder de comandar e conduzir a vida em sociedade, no caso da autoridade pública, a vida da criança ou adolescente, no caso dos pais, corresponde uma responsabilidade. A autoridade pública responde pelos atos praticados contrários ao bem comum, na medida em que tais atos afetam direitos públicos e privados dos cidadãos. Estes podem exigir-lhe, individual ou coletivamente, condutas condizentes com o cargo ocupado, por meio dos instrumentos judiciais, ou por meio da pressão política.

Quanto aos pais (ou a quem exerça os poderes decorrentes do poder paternal), deve-se-lhes cobrar a observância dos preceitos garantidores dos direitos da criança e adolescente. Não serão os filhos que lhes fiscalizarão ou exigirão (juridicamente) o exercício deste poder, uma vez que, por defeito de idade, são limitados para agir jurídica e judicialmente.

Neste espaço se interpõe e se justifica a participação da sociedade civil e do Estado no sistema como garantes dos direitos da criança e do adolescente, prioridade absoluta ( $\mathrm{CF}$, art. 227). A interferência se justifica em virtude de a pessoa do incapaz necessitar de assistência até o momento em que se presume ter adquirido plena capacidade de agir. Faltando o círculo familiar a essa função, deverão outros círculos sociais socorrer o incapaz. Esse caráter funcional dos poderes familiares coloca sob a fiscalização da sociedade a administração dos poderes outorgados às pessoas no âmbito familiar ${ }^{55}$

O dispositivo constitucional que afirma que a familia é base da vida em sociedade (CF, art. 226, caput) pode ser apontado como fundamento da ingerência

54. Para melhor cxplicação do conccito de sociedade natural, ver Antônio Jorgc Percira Júnior, op. cit. (cit. 35), pp. 50-53

55. Louis Joserrand, L'esprit des droits et leur relativité, Paris, Daloz, 1927, pp. 87-93. 
externa na família. Enquanto base da vida em sociedade, a família deixa de ser um assunto de índole exclusivamente privada e passa a ocupar o eixo das preocupações institucionais do Estado, ao lado dos direitos e garantias individuais. Outro dispositivo constitucional reforça essa interferência do Estado. Trata-se do art. 226, $\S 8^{\circ}$, que autoriza a proteção da família na pessoa de cada um de seus membros. ${ }^{56}$

É fato que os pais têm competência originária para gerir os direitos e deveres dos fillhos e levar adiante sua educação. Discute-se se essa competência seria, além de originária, exclusiva. Quando se entende que apenas os pais podem ser titulares do poder familiar, na hipótese da não existência dos pais, extingue-se totalmente o poder familiar e surge como sucedâneo a figura da tutela, ou, mais precária que ela, a guarda. É a posição de Santos Neto, para quem "somente se pode cogitar de poder paternal em havendo o vinculo de filiação (natural ou decorrente de ficção legal) a ligar os sujeitos ativos e passivos" 57

Sob esse prisma, a distinção entre titulo e exercicio do poder familiar é muito importante. Mesmo quando não existe mais o poder familiar (titulo), boa parte de suas funções pode permanecer (exercício) sob outras formas (guarda ou tutela), uma vez que alguns de seus atributos deverão continuar sendo exercitados, pelo fato de o incapaz por defeito de idade necessitar de alguém que, no exercício pleno de sua capacidade, complemente sua incapacidade de agir e o conduza à maturidade.

Quando um sistema jurídico permite separar integralmente o poder de ingerência na vida privada do menor do título de filiação como ocorria no Direito Romano, onde a filiação, por si só, não implicava a patria potestas -, o poder familiar pode subsistir independentemente dos pais, de modo que alguém sem o status jurídico de pai poderia assumi-lo. Há quem defenda essa possibilidade, propugnando pela conversão da "autoridade parental" - onde se vincula o poder familiar à filiação natural ou legal - em "autoridade familiar", 58 pela qual o título se torna transferível a terceiros, com carga total de poderes, deveres e vantagens que costumam acompanhar os pais, quando gerenciam pessoalmente o poder familiar.

Pontes de Miranda, em obra de 1917, apresenta um argumento que inspira semelhante modo de pensar. Em defesa da adoção, afirma que o poder familiar não tem como fonte essencial o nascimento biológico, e que a relação familiar "mais se funda na interdependência ou mesmo dependência espiritual do que em simples circunstâncias estranhas à vontade, como o nascimento."59 Naquela época, vivia-se

56. O valor social do privado $\mathrm{e}$ do individual pode ser constatado ainda no fato de que ao lado da insistência c da força do princípio da dignidade humana, coloca-sc hoje o principio da finşũo social, que integra uma sćric de institutos historicamente vinculados ao Dircito Privado: propricdade, contrato, posse, cmpresa, família. Isso reforça o caráter intervencionista una familia. Além disso, toda a rede de proteção dos dircitos fundamentais scrve como justificativa para ingerência da autoridade pública cm âmbitos relacionados ao Dircito Privado.

57. Josć Antonio de Paula Santos Ncto, op. cit. (cit. 6), p. 75.

58. Annc-Maric Leroyer, op. cit. (cit. 38), pp. 587-606.

59. Pontes de Miranda, Direito de Familia. Rio de Janciro, Jacintho Ribciro dos Santos, 1917, p.313-314. 
sob a diferenciação dos filhos legítimos e ilegítimos, a despeito do fato geração ser idêntico nas duas situações, o que demonstra que em face do Direito Positivo - enquanto ordenação da vida em sociedade - o reconhecimento social da filiação se sobrepunha à questão biológica, ocasionando situações jurídicas diferenciadas para os nascidos sob uma ou outra constituição familiar. Nesse mesmo sentido está o fato de o ordenamento jurídico então vigente equiparar o filho adulterino ao filho desconhecido (patre nullo ( $^{60}$ : novamente, o fato biológico era preterido diante de um quadro sócio-cultural julgado merecedor de maior proteção que a criança concebida fora do lar conjugal.

Naquele contexto cultural, o Direito Positivo se importava mais em resguardar a situação dos pais casados, protegendo a familia legitima. Hoje, a situação dos filhos menores de idade se impõe hierarquicamente como mais importante, de modo que deve prevalecer o critério que melhor atenda à situação da criança ou adolescente, podendo ser o laço biológico ou o laço sócio-jurídico, conforme este ou aquele seja aferido como a melhor situação alcançável. A melhor situação alcançável é aquela que reproduz de modo mais perfeito a família natural, ou pelo menos confere mais beneficios ao menor, em comparação com as demais possibilidades reais, sem por em risco sua constituição psíquica, física ou moral.

Sob a égide do melhor interesse da criança, que vige na atualidade, poder-se-ia indagar se não seria o caso de se admitirem como sucedâneo integral do poder familiar determinados casos de tutela civil que não chegam a se converter em adoção por força de impedimento natural, que não autoriza a adoção por afetar o título de filiação em desacordo com a ordem das coisas. É o caso dos avós ${ }^{61}$ ou do irmão mais velho, quando agem como substitutos dos pais. Não recebem da lei um tratamento mais benévolo, que facilitaria o exercício do poder de tutela. Não dar esse tipo de tratamento aos avós ou irmão mais velho - em sendo ele capaz e apto para educar o mais novo - nestas hipóteses, equivaleria a apenar o tutor, e, logo, o próprio menor.

Se um dia, sob a égide da filiação ilegítima, foi permitido usar-se de uma ficção (pois dizia-se desconhecer a paternidade de pessoa cujo pai era perfeitamente identificável) para alcançar um efeito socialmente conveniente para os pais, não há de ser descartada a possibilidade de transferência do título de autoridade familiar àqueles que exercerão os poderes a ele inerentes, mesmo não sendo os pais, em benefício dos menores, quando esta transferência não colocar em risco a formação moral, psíquica e física da criança ou adolescente. Todavia, exposta a idéia, não se lhe dará mais atenção neste trabalho.

Enquanto poder funcional, o exercício do poder familiar deve ser feito em atenção a um dever fundamental. O seu titular deve administrá-lo como o instrumento mais adequado para auxiliar na formação da personalidade da pessoa em

60. Idcm, p.313-314.

61. Cf. se disse anteriormente, no Mćxico, os avós recebem a integralidade dos poderes que os pais dispunham, sc sobrevivem a cles ou os sucedem após a perda judicial do poder familiar: 
desenvolvimento. ${ }^{62}$ Os pais, ou quem lhes faça as vezes, legitimam o uso desse poder à medida que cumprem o dever de formar o filho segundo os traços característicos da dignidade humana. É o limite mínimo do exercício desse poder, que pode ser distorcido e resultar em abuso ou omissão. Por isso, o responsável de movimentar tais prerrogativas será fiscalizado pelo Estado e pela sociedade civil.

2. Aspectos sócio-políticos: competências dos círculos sociais com relação ao poder familiar.

2.1. "Status": a posição do indivíduo perante o Estado e o grupo familiar.

Para melhor estudo do grau de relação entre os círculos sociais (família, Estado, sociedade) em matéria de poder familiar, convém tecer algumas considerações sobre o grau de relacionamento dos grupos com os indivíduos que deles façam parte. Antonio Cicu oferece uma linha de reflexão que esclarece como pode ser compreendida a relação do indivíduo com os agrupamentos humanos.

No estudo que desenvolveu acerca do conceito de status, Cicu reexamina as bases da relação do cidadão com o Estado, estabelecendo um parâmetro diferente do que se tinha até éntão.

Segundo ele, quando se entende o Direito Público a partir do paradigma do Direito Privado, costuma-se ler os poderes atribuídos ao Estado com relação ao indivíduo sempre sob uma óptica de limitação da liberdade pessoal. Cicu $^{63}$ faz uma releitura dessa situação, chamando a atenção aos benefícios gerados ao ser humano nessa relação com o Estado, indo além do sentido negativo de limitaçầo.

Uma vez que o conceito de Direito subentende o de sociedade só há Direito quando há pluralidade de pessoas convivendo em mútua relação -, antes de se falar dos direitos, individualmente considerados, deve-se atentar para a relação natural de pertinência do indivíduo a uma dada coletividade. As conseqüências dessa pertinência não poderiam ser lidas simplesmente como redutoras da liberdade pessoal, pois a liberdade individual já vem contornada, envolvida, desde sua gênese, em uma dimensão social.

As exigências da convivência social deveriam ser respeitadas por todos, como decorrência imediata da condição humana, afastando-se a idéia liberal da individualidade total do homem no estado de natureza, na perspectiva de um contratualismo social com a idéia subjacente de que o homem seria, por natureza, e de modo originário, um ser exclusivamente individual, restando a sociedade como uma criação artificial e limitadora do ser humano.

62. Quanto à interferência do Poder Público (Judiciário) na condução da educação dos menores, na Itália, veja-sc Paolo Zatti, "Rapporto educativo e intervento del giudice", pp. 185-317.

63. Antonio Cicu, "Il concetto di 'status'". Studi in onore di Vicenzo Simoncelli", Napoli, Jovenc, 1917pp. 60-74. 
Cicu critica a escolha do contrato como modelo para explicar o fenômeno da vida em sociedade. O paradigma contratual ilustra, segundo ele, a tendência de se observar a realidade social sob a perspectiva jusprivatista, que dominava a Europa após o desenvolvimento do Direito comum, inspirado no Direito Privado Romano e recuperado nas universidades a partir do século XIII. ${ }^{64}$

Observando o plano do ser, para fundamentar o dever-ser, percebe-se que há relação orgânica entre os membros de uma comunidade, ${ }^{65}$ anterior à percepção dos direitos individuais. A partir dessa perspectiva, pode-se concluir que antes de se reconhecer como ser individual, o homem é, por força da natureza e dos fatos, um ser social.

A condição social humana teria servido, em certas épocas e locais, para justificar abusos com relação à condição individual, de modo que muitos intelectuais pós-Renascimento fizeram uma leitura negativa da sociabilidade natural, construindo teorias (contratualismo social), nas quais se exaltava a dimensão individual como sendo a única do estado natural do ser humano. Pretendiam recuperar o valor do individuo em face da coletividade. Todavia, lograram ir além. Dado o efeito pendular que costuma acompanhar as mudanças históricas, terminou-se por alimentar o individualismo a ponto de, mesmo em nossos dias, ser necessária uma reação retificadora dessa postura, sob o risco de se abusar da pessoa, novamente, ao desconhecer sua condição social.

Não se deveria atribuir caráter negativo à situação de dependência perante o agrupamento. A pertinência do indivíduo ao corpo social possibilita-lhe o acesso a um universo de possibilidades que complementam substancialmente seu desenvolvimento pessoal. Somente a convivência permite-lhe desenvolver virtudes relacionadas ao serviço e ao interesse sociais. Não significa, assim, redução da condição individual humana, mas seu complemento necessário.

Concluía Cicu que onde se via, sob a óptica privatista, diminuição da personalidade - sujeição à soberania estatal -, dever-se-ia notar a sublimação da personalidade. Onde se vislumbrava simples sujeição do indivíduo, dever-se-ia reconhecer uma igualdade de sujeição de todos, como um âmbito de solidariedade. Como membros de um organismo, não mais se deveria falar que o individuo tem dependência perante o Estado, senão que entre eles se estabelece uma relação de interdependência.

Nesta perspectiva, a pessoa não se veria tolhida pelo grupo, mas potencializada ad maiora em função dele: no âmbito do grupo sua personalidade se expande para atender a fins maiores que ela própria. Na verdade o processo de educação ilustra bem a necessidade dos demais (vida em sociedade) para formação do indivíduo.

Mas, para Cicu, esse caráter associativo era personificado no Estado, confundido com a sociedade política, de modo que se tornou defensor do fortalecimento

64. Idcm, p.66.

65. Ressaltc-se que Antonio Cicu não diferenciava o conceito de comunidade do conccito de sociedacle, o que fez Ferdinand Tönnics cm. Comunidacl y socieda, Bucnos Aircs, Editorial Losada, 1947, c também Jacques Maritain $\mathrm{cm} O$ homem e o Estado, $4^{4} \mathrm{ed}$., Rio de Janciro, Agir, 1966 . Cicu trata a familia e o Estado indistintamente como comunidades. 
do Estado. Por isso se entende necessário temperar a concepção de Cicu com a visão de Maritain, de modo a se dar o real peso à sociedade civil antes de atribuir ao Estado a força motriz da vida em sociedade.

Quando se confere todo o poder ao Estado, tomando-o como a fonte dos poderes públicos, cria-se o risco dos Estados totalitários, os quais se justificam usando do argumento de serem a "sociedade civil": reduzem a sociedade civil ao aparato burocrático estatal manipulável por quem detém as chaves do poder em determinado governo. Antes de fazer parte do Estado, o indivíduo faz parte da sociedade civil.

Cicu intuiu que o individualismo não respondia às necessidades autênticas da pessoa, mas não conseguiu restaurar a importância da sociedade política como realidade prévia e mais importante que o Estado. ${ }^{66}$ Com as idéias desenvolvidas por Maritain, pode-se corrigir a leitura de Cicu que levaria à exaltação do Estado como organismo que poderia agir por si, sem a necessidade de justificar seus atos à sociedade civil.

Quanto à sociedade familiar, Cicu afirmava que, à semelhança do status civitatis, também no âmbito familiar se estabelecia uma relação orgânica entre as pessoas, pelo que decorriam deveres para os seus membros.

Para o civilista italiano o "status" é a situação que se estabelece não só por decorrência da relação Estado-cidadão, mas também sempre que o individuo se apresenta como membro de um todo superior, que possui um escopo comum. "Antes de tudo, isso ocorre na famillia". ${ }^{67}$ O status é "a relação ou vínculo juridico que liga o indivíduo ao agrupamento":8 (tradução nossa).

Essa relação orgânica do indivíduo com o Estado - na visão de Cicu -, ou com a sociedade política - na concepção de Maritain -, também se verifica com relação à família. No entanto, o vínculo é mais forte no âmbito familiar que no âmbito coletivo estatal, pois "na familia é mais puro o momento do dever, também porque a própria destinação à função é aqui pre-ordenada e individualizada, sendo mais restrito o campo da liberdade e da vontade". Na sociedade familiar mais facilmente se percebe a configuração do status do que na sociedade estatal, pois na família fica mais nítido "o conceito de interdependência e solidariedade; a característica de direito-dever; a exclusão do interesse egoísta, do poder de aquisição, de disposição e de renúncia; a subordinação a um fim" ${ }^{69}$ (tradução nossa).

As idéias de CICU serviram como referência para o pensamento do

66. Vale lcmbrar que o Estado é entidade (artificial) criada pela socicdade política.

67. Antonio Cicu, op. cit (cit.63), p. 60.

68. Idem, p. 70. No original: "Status è pertanto il rapporto o vincolo giuridico che lega il singolo nell'aggregato".

69. Antonio Cicu, op. cit. (cit. 63), p. 73. No original: "Più evidente e sicura è invero la necessitci che determina e tien fermo l'aggregato famigliare: piì puro quindi il momento del dovere, anche perchè la stessa destinazione alle funzioni è qui preordinata ed individualizzata, sicchè molto più ristretlo è il campo della libertà e volontà". Adiantc: "Ma tulto ciò non impedisce che in confionto dello s.civitatis abbiano qui maggior risalto il concetlo di interdipendenza e solidarieta; la caratteristica di diritlo-dovere; l'eschusione dell'interesse egoistico, del potere di acquisto, di disposizione e di rinuncia; la subordinazione ad an fine." 
Direito de Familia como âmbito do Direito Social, ${ }^{70}$ servindo, ainda, de contraponto ao entendimento de uma total autonomia da vontade no âmbito familiar. Cada membro da família deve respeitar princípios decorrentes da relação familiar, que transcende a individualidade.

A concepção de família possui uma nota característica comum à concepção de Estado e de sociedade política (sociedade civil): os três agrupamentos incluem-se na categoria de sociedade. São realidades pretendidas racional e moralmente pelos homens, dotadas de fins particulares a cada uma, e de fins comuns aos três grupos.

Quanto aos fins comuns, deve-se esclarecer uma ordem de precedência entre as três sociedades, de acordo com a acessibilidade e o poder de cada uma delas sobre a vida do indivíduo. O bem comum familiar, por exemplo, é pré-requisito para o bem comum geral.

\subsection{Precedência da família dentre os círculos sociais.}

Ao grau de relacionamento e de intimidade que se partilha com determinado grupo do qual se faz parte, corresponde uma maior interdependência sóciojurídica. Como o indivíduo faz parte de diversos grupos, torna-se titular de direitos e deveres perante eles, proporcionalmente ao grau de interdependência com cada um deles.

As pessoas são ao mesmo tempo cidadãs (relação perante o Estado), membros (perante a sociedade civil) e parentes (perante a família), guardando com cada um desses círculos alguns deveres e direitos. Essa tríplice pertinência justifica a interferência de um círculo no outro, uma vez que todos eles se unem na função principal do bem comum, e todos eles se constituem em serviço às pessoas que os compõem.

Pode-se imaginar a pessoa envolta por três círculos: mais próximo a ela está a família, seguida pela sociedade (nas diversas entidades em que possa se manifestar e na própria sociedade política) e pelo Estado. O desconforto social do circulo mais intimo faz-se sentir no meio social seguinte, e o desconforto deste, por sua vez, reflete no Estado.

No que se refere ao menor de idade, a atuação insuficiente do primeiro círculo - família - exige de imediato a atuação do meio social seguinte. A insuficiência deste meio leva ao Estado.

No entanto, ante a disfunção dos círculos sociais mais próximos ao indivíduo, o Estado é a entidade a quem primeiro se cobra uma providência. Nada mais razoável, uma vez que o Estado, entidade artificial, tem função instrumental de gerir os interesses da sociedade, e deve assumir, em primeiro lugar, a responsabilidade pelo individuo incapaz desatendido pelos pais, em nossos dias.

O Estado assume a primeira posição na rede protetora da pessoa. Mas nem por isso deve manter-se como executor exclusivo da função de zelar pela situação

70. São também de Antonio Cicu, Il diritto di famiglia, teoria generale. Roma, Athencum, $1915 \mathrm{c}$ Filiazione, Torino, UTET, 1951. 
do menor de idade, porque não compete a ele incumbir-se sozinho de tarefas cuja competência originária era de outros agrupamentos (família e sociedade civil) ou cuja competência concorrente (ou comum) deva com eles compartilhar.

A relação entre os três principais círculos que envolvem o indivíduo pode ser regulada pelos princípios da subsidiariedade e da cooperação. Subsidiariedade do Estado, por exemplo, no que é de competência exclusiva ou privativa dos demais círculos, e cooperação no que é competência concorrente entre eles.

Necessária ainda se faz a intervenção de círculos sociais diferentes da família, em razão da prioridade absoluta da criança e do adolescente, princípio que integra nosso sistema jurídico, e do enfraquecimento da instituição familiar, círculo competente originariamente para cuidar dos interesses do menor.

\subsection{Estado de Direito e a interferência no exercício do poder familiar.}

O que fundamenta a intervenção do Estado em matéria de poder familiar? $\mathrm{Na}$ atualidade, essa intervenção se apóia, em último termo e de modo fundamental, no dever do Estado de garantir os direitos fundamentais de todos os seus súditos. ${ }^{71}$

A consolidação do conceito de Estado de Direito, como instrumento ideal a serviço da convivência pacífica e harmônica em sociedade, importou no fortalecimento progressivo dos poderes estatais. Em função disso, o Estado foi dotado de estrutura privilegiada, dispondo de meios apropriados para executar suas atribuições. Um imenso poder foi-lhe conferido para usar no interesse dos cidadãos. Por isso o Estado pode ser constrangido a assumir a responsabilidade de proteger e garantir os direitos fundamentais dos seus súditos. Apresenta-se hoje como o principal guardião dos direitos fundamentais do indivíduo. ${ }^{72}$ Não-obstante sua posição central nesta matéria, não conseguirá êxito sem assistência da sociedade civil, sobretudo no contexto da complexa sociedade de massas contemporânea.

71. Há competência comum do Estado $\mathrm{cm}$ relaçào aos pais, litulares do poder familiar, $\mathrm{cn}$ fàce do filho, quanto a alguns poderes-deveres, conforme sc analisará adiante, no corpo do texto. Há, também, poderes-deveres que são de competência exclusiva ou privativa dos pais, de modo que somente subsidiariamentc o Estado intervirá, como medida extrema diante da impossibilidade de os pais levarcm a termo esses deveres.

72. Mcsmo perante documentos como a Declaraçāo Universal dos Dircitos do Homem, promulgado pcla ONU, cm 1948, o Estado ć organismo decisivo na proteção dos dircitos fundamentais. Assim, no art. 8" do referido diploma, lêे-sc: "todo homem tem direito a receber dos tribunais nacionais competentes" remédio efetivo para os atos que violem os direitos fundamentais que lhes sejam reconhecidos pela Constituição ou pela lei". A Constituição ć o documento formal que inaugura o Estado. Mas as lcis c os tribunais scrão administrados pclo Estado. Scm a atuação adequada do Estado, nos órgãos que o represcntam cm cada csfera, nào havcrá tutcla verdadeira dos dircitos da pessoa humana. Ao mesmo tempo, valc a pena lembrar que mesmo que a Constituiçào possa scr apontada como a certidào de nascimcnto do Estado, constituido por cla, a rigor, pcrante o Dircito Constitucional, cla ć prévia ao Estado, pois ć concebida no scio de uma Asscmbléia Constituinte, momento $\mathrm{cm}$ que ainda nào existe, formalmente, o Estado que está scndo construído. A Assembléia Constituinte ć o exemplo mais patente de organização da socicdade civil na construção do Poder Público. 
2.3 Intervenção do poder público na condução do poder familiar.

O poder familiar é uma das incumbências do círculo social familiar que sofre ingerência da sociedade civil e do Estado. De modo especial o Estado contemporâneo, no uso do monopólio legislativo, e por meio das instituições públicas, interfere no exercício ou na titularidade do poder familiar, direta ou indiretamente, quando fiscaliza a situação dos menores de idade, para garantir que seus direitos sejam respeitados.

A motivação dessa fiscalização, durante o século XIX e parte do século $\mathrm{XX}$, esteve concentrada no interesse da sociedade em precaver-se da má formação dos futuros cidadãos. ${ }^{73}$ Hoje, com o protagonismo da criança e do adolescente pensa-se, primeiro, ${ }^{74}$ no interesse deles e, depois, no interesse dos demais membros da sociedade.

O Estado contemporâneo, cingido pelo princípio da legalidade, para intervir em matéria de direito do menor, necessita agir conforme uma previsão legal, ficando vinculado ao limite fixado em lei. Dessa forma, pode-se acompanhar o histórico da intervenção do Estado brasileiro em matéria de menores por meio da legislação. ${ }^{75}$

As recentes leis relativas aos direitos da criança e do adolescente foram concebidas sob a égide da proteção integral. Sob tal conceito pretende-se resguardar a situação de todos os menores, nos vários âmbitos de sua vida, não se limitando à esfera penal. Isso aumentou o poder de interferência do Estado e também sua responsabilidade. Mas a lei, sabiamente, envolveu a sociedade inteira nessa nova ordem normativa acerca dos direitos da criança e do adolescente.

Sob inspiração da doutrina da proteção integral, o ECA perfilou os direitos dos menores em detalhes. Como o poder familiar é o principal instrumento para intervenção na vida da pessoa em condição peculiar de desenvolvimento (cf. supra, ponto 1), o titular deste poder é o maior responsável pela garantia dos direitos das crianças e dos adolescentes.

Ao descrever os direitos que devem ser resguardados à criança e ao adolescente com prioridade absoluta, o legislador indiretamente esclareceu e expandiu

73. Irenc Rizzini, O século perdido - raizes históricas das politicas priblicas para a infância no Brasil, Rio de Janciro, Editora Universitária Santa Úrsula / Amais Livraria c Editora, 1997, p. 34. Na p. 64, pode-sc lcr: "Ao se buscar na literatura histórica referências sobre o espaço reservado à criança na sociedade brasileira do século XIX para o XX, percebe-se claramente que "a criança" que mais aparecia era aquela que, aos ollos da elite, carecia da proteção do Estado e precisava ser 'corrigida' ou 'recducada' Eram os 'cxpostos' os 'orphaosinhos', os 'pobres meninos abandonados', as 'creanças criminosas' os 'menores delinqüentes' e assim por diante. Onde constava algo relativo à infância ou à juventucle. lá estava implícita a iléeia de periculosidade, carregada da ambigiiidade anteriormente assinalada: ou a criança personificava o perigo ou ameaça propriamente ditos ('viciosa, pervertida, criminosa...') ou era apresentada como potencialmente perigosa ('cm perigo de o scr...').

74 . Dever-sc-ia pensar, ao menos, por exigência do principio da prioridade absoluta da criança c do adolcscentc, csboçado no art. 227 da CF.

75. Essa tarcfa ć levada a termo no capitulo seguinte (ponto 2.10). Neste momento, importa cnfocar a ampliação dos poderes de intervenção do Estado $\mathrm{cm}$ matéria de dircitos da criança $\mathrm{c}$ do adolescentc. 
os efeitos que devem ser alcançados pelo exercício do poder familiar. Sem essa previsão legal, não seria possível que o Estado interviesse legitimamente nessas matérias. Ampliou-se, dessa forma, o conteúdo do poder familiar com relação às disposições do CC. Por isso, indiretamente, o Estado, ao fiscalizar o respeito aos direitos da criança e do adolescente (descritos no ECA), termina por avaliar o exercício do poder familiar. Em razão do princípio da descentralização, ${ }^{76}$ essa função será compartillhada com a sociedade civil, segundo adverte Sálvio de Figueiredo Teixeira: "Ao lado de uma participação mais ativa da sociedade, cumpre ao Estado executar, aprimorar e fazer cumprir as leis quie editou, formular as que faltam, prestigiar os atos internacionais de que é signatário, transformar sua postura paternalista em gerador de oportunidades" 7 ?

Quando não há laços familiares que fornecem ao menor de idade a atenção conveniente, ou a atenção dos pais é insuficiente ou prejudicial, as demais esferas deverão entrar em ação para socorrê-lo. Cabe estudar como deve se operar a atuação de cada esfera de coletividade nessas situações, para evitar que haja abusos e omissões.

\subsection{Competência do Estado, da sociedade e da família: em busca de um critério.}

Convém que a relação da familia com a sociedade civil e com o Estado seja pautada por um critério que oriente quando e em que âmbitos esses agrupamentos poderão interferir na condução da vida do indivíduo menor de idade, não emancipado. Esse critério tem por fundamento a divisão de competências materiais ou formais entre eles.

Para definir os âmbitos de relacionamento pessoal (vida privada) em que o Estado e a sociedade civil podem (ou devem) intervir, e os momentos em que se justifica tal interferência, é necessário recorrer à filosofía social (principalmente a Ética social), matéria que sofreu um eclipse com o desenvolvimento da sociologia no século $\mathrm{XX}$, e que tende a recuperar espaço nos meios científicos em face da complexidade pós-moderna, convidando ao desenvolvimento dos princípios e da noção de dever ínsita ao relacionamento social. ${ }^{78}$

Por meio da filosofia social pode-se responder, por exemplo, qual grupo tem competência originária para tratar da educação dos incapazes por defeito de idade, se é possível estabelecer uma hierarquia entre eles e quais princípios poderiam nortear a atuação harmônica dessas esferas de coletividade na tutela da pessoa humana e na promoção do bem comum.

Para disciplinar a ordem social, o Direito Positivo deve se socorrer da filosofia social, sob risco de afrontar a base das relações que se criam no seio da

76. Cf. Antonio Jorge Pcrcira Júnior, op. cit. (cit. 35), pp.99-102

77. Sálvio de Figucircdo Tcixcira. "O menor; esse desconhecido", Revista Trimestral de Jurisprudência dos Estados. São Paulo, 1990, vol. 78, p. 46.

78. Vale lembrar que também na aplicação do principio da boa-fé objetiva os deveres surgem de modo incgável, com maior força que os dircitos correspondentes. Os dircitos seguem, por via reflexa, aos deveres. Ver Judith Martins-Costa, A boa-fé objetiva no direito privado, São Paulo, Revista dos Tribunais, 1999. 
convivência. A Sociologia tem por objeto constatar o que ocorre, não diferenciando o acontecido do devido, de modo que serve à análise, mas não auxilia na resolução dos problemas sociais.

Os agrupamentos citados (Estado, sociedade civil, família) dividem competências e ocupam espaços diferenciados, tendo em vista a consecução do bem comum. Cada qual atua em um âmbito da vída social. É dificil estabelecer regras que regulem com exatidão o espaço de cada um deles. As competências de cada um são determinadas, em linhas gerais, por meio de princípios. Os princípios que orientam o relacionamento dos círculos de coletividade adquirem feição jurídica na medida em que determinam um dever-ser que vincula socialmente. Essa força deontológica converte-os em princípios juridicos.

Na hierarquia entre as entidades que envolvem o menor de idade, a família ocupa a primeira posição numa ordem de precedência, pois é o órgão imediato de sua formação. A sociedade civil ("sociedade política", em Maritain) está em um segundo plano, pois precede o organismo estatal na existência, o qual, por sua vez, é produto dela e a ela deve servir. Em terceiro lugar, coloca-se o Estado, estrutura (instrumental) que tem por função zelar pelos serviços públicos como representante da sociedade política na gestão dos poderes que pertencem a ela.

Os três círculos sociais aparecem relacionados no $\$ 1^{\circ}$ do artigo 226 da CF, sob o tílulo VIII da Carta Magna que, convém recordar, trata "da ordem social" Lê-se neste dispositivo da CF que "a família, base da sociedade civil, terá proteção especial do Estado" (grifos nossos). Essas palavras expressam, de modo sintético, a relação de interdependência entre eles, segundo a hierarquia acima: a familia é a base (célula social), sem a qual não se constitui a sociedade civil (o tecido social). O Estado, por sua vez, produto que é da sociedade civil organizada, foi incumbido expressamente por ela de proteger a base da sociedade, ou seja, a família.

A família é o agrupamento social que tem maior responsabilidade na formação das novas gerações (formação corporal, espiritual e social). Por isso a sociedade política, reunida em Assembléia Constituinte, quis impor ao Estado a incumbência de protegê-la especialmente, inscrevendo-a no documento que constitui e define as competências estatais. ${ }^{79}$. "A cada círculo social corresponde o seu tipo de direito, o seu sistema. Diante das conviç̧ões da ciência, que tanto nos mostram e comprovam explicação extrinseca dos fatos (isto é, dos fatos sociais, objetivamente), o que se não pode pretender é reduzir o direito a simples produto do Estado. O direito é produto dos circulos sociais, é fórmula da coexistência dentro deles. Qualquer círculo, e não só os políticos, tem o direito que lhe corresponde" (grifo no original). ${ }^{80}$

Nas palavras de Pontes de Miranda, ter "o direito que lhe corresponde" bem poderia ser lido como ter o poder que the compete, na divisão de funções entre círculos sociais para garantir a saudável convivência humana. Nesse sentido, Johannes

79. Hcinrich Lchmann, op. cit (cit. 44), p. 273.

80. Pontes de Miranda, op.cit. (cit. 2), p. 170. 
Messner dizia que "o direito consiste em competências garantidas, isto é, em poderes seguros para fazer, ter ou exigir algo perante uma eventual violação de outrem " (grifo no original), ${ }^{81}$ comportamento exigível no seio da vida social. Afirma ainda que "as competências conferidas pelo direito devem-se às responsabilidades ligadas aos fins existenciais dos homens. "\$2

É de grande utilidade o uso do conceito de competência para que se compreenda o que cabe a cada entidade no jogo de responsabilidades em defesa dos direitos da criança e do adolescente. Nesse caso, em vez de se falar em competência legal (definida pela lei), melhor é falar-se de competência natural, ${ }^{83}$ pois precede a lei.

As competências naturais da família e da sociedade civil independem de previsão legal estatal para serem reconhecidas e operarem efeitos, apesar de o conhecimento delas ficar condicionado pela cultura ${ }^{84}$ e o respeito efetivo a elas ser garantido mediante lei.

As competências estatais, sendo o Estado um ente criado pela sociedade, necessitam de previsão legal, devendo estar enunciadas de modo claro nas constituições ou convenções públicas da sociedade civil, nas quais se deveriam definir, de acordo com uma razão de proporcionalidade e adequação, quais funções podem ser transferidas ao Estado quando couber a ele agir em nome da sociedade civil.

Apesar disso, pode ser que algumas competências estatais não estejam positivadas, por imperfeição dos documentos correspondentes, por eventual impossibilidade de previsão quando da elaboração da Carta Política, ou pelo fato de algumas delas não necessitarem de reconhecimento formal, por estarem devidamente assimiladas no contexto sócio-político.

$\mathrm{Na}$ CF brasileira pode-se encontrar um repertório imenso de competências estatais. Em quantidade menor, podem ser identificadas competências dos demais círculos sociais, incorporadas ao texto constitucional. Todavia, as competências cabíveis aos grupos diferentes do Estado, costumam ser ordinariamente descobertas com o auxilio da filosofia social.

Facilita aos operadores do direito tomar por empréstimo a conceituação de competência tal qual desenvolvida no Direito Constitucional para, a partir dela, refletir acerca das competências originárias de cada círculo social.

81. Johannes Mcssncr, Ética social, São Paulo, Quadrante, s/d, p. 211.

82. Idcm, p. 2$\rfloor 1$.

83. A palavra nctural tem sua raiz (nat.) relacionada ao supino do verbo latino nasc-or (nat-lus stum), que significa nascer. Assim tambćm as palavras nato, inato, nativo, natalidadc, naturcza, nação. Carlos Góis, Dicionário de raizes e cognatos da lingua portıguêsa, $3^{\star 2}$ cd., Rio de Janciro, 1945, pp. 206-207. Pretcnde-sc usar o qualificativo natural, nestc uso cspecifico, como referência a una realidade que nào precisa ser positiveadı para existir, uma vez originada (nascida) da siluaçüo concreta, , scm a necessidade da chancela do Dircito Positivo cstatal para cxistir. Portanto, algo nascido com a pessoa ou algo nascido de uma situação rclacional onde a declaração de vontade humana; ainda que presente, não ć a causa cficiente do fenômeno.

84. Javier Hervada, Critica introdutória ao direito natural, Porto, Rés, s/d, p. 131. 
Mais útil ao escopo desse trabalho mostra-se o critério que nomeia as competências de acordo com a extensão do poder cabivel a cada entidade, em determinada matéria. Esta competencia extensiva se subdivide em quatro tipos: exclusiva, privativa, concorrente e suplementar. ${ }^{85}$

Outro critério classificatório diz respeito à sucessão daquele que se investe da competência. Será chamada de originária a competência quando exercida pela entidade que foi originariamente investida dela. Será delegada a competência quando a entidade que a exerce sucede a uma outra, que lhe tenha delegado tal poder. ${ }^{86}$

As competências dos diversos círculos sociais - familia, Estado, sociedade política - em matéria de criança e adolescente, são percebidas especialmente por meio dos princípios que orientam a ordem social.

2.4. O princípio da subsidiariedade.

O principio da subsidiariedade, bastante desenvolvido pela doutrina social católica, apresenta-se como de grande utilidade para promover e evitar abusos no relacionamento entre os círculos sociais (família, sociedade civil entidades intermediárias - e Estado).

A palavra provém do latim subsidium, que significa "ajuda desde a reserva", ou seja, desde uma instância que não é responsável diretamente pelo cometido. Em Roma, as subsidiarii cohortes eram as tropas que estavam na retaguarda, dispostas a ajudar as tropas de primeira linha (prima acies), quando estivessem em dificuldades e impossibilitadas de sair dessa situação por conta própria. ${ }^{87}$ Há referência, portanto, ao auxílio prestado por entidades superiores, a entidades inferiores, sempre que estas não sejam capazes de atender sozinhas suas necessidades. Costuma ser aplicado na relação entre o Estado e os cidadãos (incluindo as entidades intermediárias).

Deve ser aplicado quando determinada competência de um grupo social não estiver sendo cumprida, e um outro agrupamento, mais perfeito, auxilia ou assume

85. A competência exclusiva ć aquela que não admite suplementaricdade $\mathrm{e}$ nem delegação. Somente uma detcrminada entidade tem a incumbência de excreĉ-la. A competência privativa, por sua vez, assemelha-se à exclusiva, com o detalhe de admitir delegação. A competência concortente (ou comum) a compctência que, originariamentc, ć atribuída a mais de uma cntidade. Pode scr que esta competência commm seja dividida, criando-se diferentes graus de participação das cntidades que concorrem no cxercício de um mesmo poder. Pode ser que haja participação igual das entidades na gestão do poder que llhes competc, ou pode ser que haja primazia de uma com relaçào à(s) outra(s). Neste caso, quando há reserva de certas incumbências a uma delas, a priori, por disposiçào lcgal ou por força da normatividade juridicosocial, surge a competência suplementar, catcgoria de competência concorrente. A competência siuplementar ć excrcida apenas quando a entidade que tem preferência para excrecr a competência concorrente não o faz, ou sc limita aos aspectos gerais da matéria que administra, restando à outra suplementar o excrcicio do poder dado a ambas. Cf. Josć Afonso da Silva, Curso de direito constitucional positivo, $18^{\mathrm{a}} \mathrm{cd}$., São Paulo, Malhciros, 2000, pp. 482-483.

86. Idcm, pp.483-484

87. Martincll Gifrc̀, F. "Principio de subsidiaricdad", Gran enciclopedia Rialp, $6^{\mathrm{a}}$ cd., rcimpressão. Madrid, 1991, tomo XXI, p. 707. 
a função respectiva para garantir o bem comum e/ou o bem individual de quem pode estar sendo lesado pela atuação insuficiente do grupo competente originariamente.

Adquiriu forma especialmente grata na encíclica Quadragesimo anno, de Pio XI: "ainda que seja verdade que muitas tarefas que em épocas anteriores podiam realizar também as associações pequenas, hoje somente podem levar-se a cabo por obra de grandes entidades sociais, permanece, contudo, firme e imutável em filosofia social aquele importantissimo principio que não se pode alterar nem mudar: da mesma maneira que não se deve privar o individuo daquilo que pode obter pela própria iniciativa e pelas suas próprias forças, nem atribuir-lhe a atividade da sociedade, atenta igualmente contra a justiça outorgar à comunidade superior e mais ampla aquilo que as comunidades menores e subordinadas podem conseguir e levar a bom fim. Toda atividade social deve, por sua natureza, prestar auxilio aos membros do corpo social, nunca absorvê-los nem destrui-los" 88

Conseqüente ao princípio da solidariedade, ${ }^{89}$ o princípio da subsidiariedade deve ser aplicado nas situações em que se relacionam entidades de maior e menor superioridade: Estado e municípios, municípios e associações civis, Estado e família etc.

De acordo com Rafael Llano Cifuentes, "o principio da subsidiariedade estabelece que o Estado, de um lado deve permitir sempre ao individuo è̀s sociedade menores ou intermediárias exercitarem os seus direitos e cumprirem os seus deveres na medida em que são capazes por si mesmos e, de outro, deve ajudar com a sua assistência (subsidio) nas coisas necessárias em que estes não são suficientes" 90

O principio da subsidiariedade determina que o Estado respeite as competências exclusivas e privativas das entidades menores. Deverá agir (fornecer subsídio) quando tais entidades não estiverem cumprindo, sozinhas, suas funções (competências), em defesa e proteção daqueles que possam ser prejudicados pela atuação insuficiente delas.

Esse princípio protege, portanto, a autonomia da familia e de outros grupos sociais menores, da invasão abusiva do Estado. Sempre que intervier em matérias de competência exclusiva, ou privativa, da família, deverá o Estado usar do poder jurisdicional, pois estará afetando a titularidade ou o exercício do poder familiar de modo grave.

Cabe assim ao Estado intervir na medida em que for necessária essa intervenção, de acordo com circunstâncias que a justifiquem; mas sempre permitindo o pleno desenvolvimento das sociedades intermediárias, como a família, o município,

88. Pio XI, Encíclica Quadragesimo anno, n. 79.

89. "O principio da subsidiariedade supõe os principios de solidariedade e do bem comum, sem com eles identificar-se" Joscph Cardcal Höffncr, Doutrina social cristã (versão de acordo com a $8^{*}$ cdição alcmã), São Paulo, Loyola, 1986, p. 35.

90. Rafacl Llano Cifucntes, Relações entre a Igreja e o Estado, 2" ed., Rio de Janciro, Josć Olympio, 1989, p. 52. 
a corporação, o sindicato. Todas devem ser respeitadas porque respondem a uma necessidade - e por isso têm direitos e finalidades próprias ${ }^{9 !}$ - ou porque são, no mínimo, produto da liberdade humana de associação"2 "Dupla é a fiunção da cuutoridade politic'a do Estado: garantir e promover; mas não é de modo algum finção do poder político absorver a familia e o individuo ou sub-rogar-se em seu lugar" 93

Dentre as conseqüências do princípio sob exame, apontadas por Llano Cifuentes, destaca-se a afirmação da existência de fins e direitos próprios (competências), inerentes à natureza do indivíduo, da família e das unidades sociais menores, que não resultam de transmissão ou delegação feitas pelo Estado; a consideração de que o desrespeito a esse princípio jurídico implica totalitarismo estatal, uma vez que o Estado se imiscui no âmbito de atuação de outras entidades; e a conclusão de que esse principio exprime a igualdade dos direitos e deveres dos indivíduos, da família (sociedade natural), da comunidade local (município, por exemplo), profissional (corporações), e religiosa, que devem ser respeitadas em sua autonomia, na medida do possivel. ${ }^{94}$

Pode-se perceber o princípio da subsidiariedade informando diversos dispositivos constitucionais (principalmente no título VIII da $\mathrm{CF}$, que trata "da ordem social"), e infra-constitucionais. De modo claro, pode-se reconhecer esse princípio nas normas que reconhecem aos pais os poderes inerentes ao poder familiar, de modo originário (competência originária), pois são os primeiros responsáveis pela formação dos fílhos. Ao mesmo tempo, a sociedade e o Estado devem zelar pelos menores de idade. ${ }^{\text {s }}$

\subsection{Competências extensivas e princípios reguladores.}

A existência de diferentes competências entre os diversos círculos sociais responde necessidade da sociedade de dividir funções entre os que compõem o tecido social. As mútuas interferências que se façam necessárias nessa divisão de poderes de ação, para suprir a insuficiência de uns com relação a outros, geram uma

91. Também a Declaração dos Direilos do Homem, da ONU (10/12/1948), cstabclece csse caráler natural c fundamental da família "a familia é o micleo natural e findamental da sociedade e tem direito á proteção da sociedade e do Estado" (art. 16).

92. O libcralismo foi um dos fatores responsáveis pela atomização da sociedade mediante a desconsideração dos grupos intermediários que serviam de ponte cntre o indivíduo c o Estado: "subestimando ou debilitando os grêmios e corporaşóes profissionais, a familia eo municipio, conseğuinse - como apontam muitas correntes de pensamento atual - que o individuo se sinta impotente e insignificante, ensinando-lhe a projetar todos os sens poderes humanos na figura do lider; do Estado" Rafacl Llano Cifucntcs, op. cit. (cit. 90)., p. 53.

93. Pio XI, Enciclica Quadragesimo anmo, n. 36.

94. Rafacl Llano Cifuentes, op.cit. (cit. 90), pp. 56-55.

95. A título cxcmplificativo, pode-se ver Cl; arts. 229 e 22795; CC, art. I.634; ECA, art. 22. Enunciado do $\mathrm{CC}$, art. 1.634: "competc aos pais, quanto à pessoa dos filhos..."; Enunciado do ECA, art. 22: "aos pais incumbe o dever de sustento...". 
certa perda, que é o reflexo da disfunção de um ente social no conjunto maior da vida coletiva. De acordo com a categoria de competência que é afetada, haverá maior ou menor perda. ${ }^{96}$

Quando há competência exclusiva de um círculo social, com relação a determinada matéria, a falta do respectivo círculo jamais será compensada pela atuação de outro. Haverá uma lacuna que não será preenchida pela entidade que o sucede, por mais que se trabalhe para suprir esta carência.

Quando se trata de competência privativa, a ausência da entidade originariamente competente também causará prejuizo, pelo menos até que outra entidade venha a assumir sua função. A entidade substituta, por outro lado, não costuma alcançar o nivel de atendimento dispensado pela originária, de modo que o exercício de competência delegada (pela sociedade, pela lei ou pelas autoridades) de modo habitual será qualitativamente pior. Mas, nessas hipóteses, o prejuizo será menor se comparado à ausência das entidades encarregadas de competências exclusivas.

As competências comuns, ou concorrentes, são as que podem ser assumidas indistintamente por grupos diferentes, de modo que a ausência de um círculo social pode ser suprida pela atuação de um outro círculo, com menores perdas.

Em matéria de gerenciamento do poder familiar, as competências concorrentes, quando as houver, assumirão a feição de competência suplementar, resguardando-se a precedência da família no cumprimento dos encargos relativos aos filhos. Como a família é o principal círculo social com relação à formação integral da pessoa, ela (os pais) terá a competência preferencial; a sociedade civil e o Estado, competência suplementar.

A subsidiariedade está mais associada às competências exclusivas ou privativas, e menos às competências concorrentes, pois neste caso há paridade entre as sociedades encarregadas de cumpri-las, de modo que o dever se impõe a todos os círculos, respeitando-se a ordem de precedência da entidade que goza de competência preferencial.

Para diferenciar essas situações, julgou-se por bem trabalhar com um

96. Talvez se possa ilustrar as ausências das cntidades competentes originariamente, $\mathrm{cm}$ cada um dos tipos de compctência, por meio da imagem do corpo lıumano com dificuldades cm scus órgãos. $\mathrm{O}$ cxemplo é imperfeito mas pode auxiliar na comprecnsão geral das distinções que scrào apontadas. A ausência de cntidade que possui determinada competência exclusiva no tecido social poderia scr comparada a uma lesão no sistema nervoso do corpo. Como as células nervosas não se reconstituem, assim tambćm é impossivel suprir com perfeição a falta daqucla entidadc. A disfunçào de detcrminado circulo social $\mathrm{cm}$ matćria que ć de sua compctência privativa, podcria scr comparada à disfunção de um órgào do corpo que ć substituívcl por outro, scm que se mantenha o potencial original. Scria o caso, por cxcmplo, do coraçào humano. Por mais que um transplante garanta a funcionalidade principal do órgão, o pacicnte difícilmente alcançará descmpcnho similar se cstivessc com o coração original c saudável. A compctência comum scria aquela que pode ser cxcrcida por órgãos múltiplos, como os pulmões, rins, olhos. Tambćm a ausência de um destes órgàos gera perdas ao corpo. Alćm disso, para cstender o cxemplo à competência suplementar, pode-sc pensar no caso das mãos. Um destro tem maior necessidade de sua mào dircita que da csquerda. Para cle, a mão dircita, apesar de ser da mesma natureza que a esquerda, tem preferência, pelo fato de ter maior habilidade c scrvir mclhor às funções requeridas para as mãos. 
segundo princípio, intimamente relacionado ao princípio da subsidiariedade. Trata-se do princípio da cooperação, que, em último termo, poderia ser reduzido àquele.

O princípio da subsidiariedade seria invocado, portanto, quando não houvesse igualdade de competência (casos de competência exclusiva ou privativa da família, por exemplo) entre os círculos sociais, e um deles precisasse intervir em socorro da pessoa que não é atendida convenientemente pelo grupo social originariamente competente.

Pode-se fazer aplicação desse raciocínio ao dever de educar. A educação abrange as áreas de formação moral, religiosa, intelectual, e profissional. Cada um destes âmbitos pode ser classificado como de competência exclusiva ou privativa dos pais, ou, ainda, como competência comum dos pais, da sociedade civil e do Estado. Esta última categoria de competência, por sua vez, pode se apresentar dividida entre competência preferencial (ou geral) e suplementar, quando se atribui maior responsabilidade a um grupo que a outro, apesar de ambos serem encarregados da mesma função.

A educação moral do incapaz por defeito de idade, por exemplo, é competência privativa dos pais. O Estado não concorre com eles, e não pode usurpar deles tal competência. Quanto à formação profissional, por sua vez, há competência preferencial (ou geral) da família, e competência suplementar do Estado. Quando essa competência estatal é atualizada, está-se aplicando o princípio da cooperação. No primeiro caso (educação moral), havendo insuficiência dos pais, o Estado deverá intervir, de acordo com o principio da subsidiariedade, dando suporte aos pais para que ela se efetive, ou substituindo-os quando este suporte não for suficiente para garantir aos filhos a educação moral a que têm direito.

De modo geral, a educação do menor é competência originária e privativa (apesar de não ser exclusiva) da família. Assim, algumas das aplicações recomendáveis de respeito ao princípio da subsidiariedade, seriam: o reconhecimento jurídico do ensino dado em casa (que poderia ser aferido oficialmente por exames públicos de participação livre), a possibilidade de os pais escolherem o tipo de educação que desejam para os filhos (indo-se além da escolha da escola) e a possibilidade de interferirem ativamente nos currículos escolares das escolas públicas e particulares. ${ }^{97}$

Ainda nesse sentido, diz Fernando Pimentel Cintra que "a educação não pode ser atribuida ao Estado da mesma forma com que se atribui à familia e à sociedade. O Estado, como sociedade maior e mais perfeita, aparece neste quadro com a função subsidiária de promoção e proteção" ${ }^{88}$ A educação compete privativa mas não exclusivamente aos pais, de modo que deve o Estado respeitar a precedência dos pais e auxiliá-los na função, se for necessário (subsidio). Mas não pode arrogar a

97. Fernando Pimentel Cintra, O principio da subsidiariedade e as formas de parceria aplicáveis ao ensino público de nivel básico. Tese de doutoramento. Faculdade de Dircito da Universidade de São Paulo, São Paulo, 1999, p. 72.

98. Idcm, p. 74. 
si, em concorrência com os pais (respeitando-se os direitos fundamentais do filho), o direito de educar.

2.6 Princípio de cooperação.

O principio da solidariedade antecede o princípio da subsidiariedade.

O desenvolvimento científico do princípio da subsidiariedade foi motivado pela necessidade de se corrigir o excesso, a interferência abusiva do Estado, quando chegou a ponto de exaurir as competencias naturais, exclusivas, privativas ou comuns (preferenciais) das entidades sociais menores.

Ambos os principios se fundam na sociabilidade humana; todavia, cada um deles está relacionado a diferentes valores. Enquanto a solidariedade se apóia na sociabilidade, a subsidiariedade motiva-se pelo respeito à liberdade humana, que deve ser promovida e auxiliada, para garantir a autonomia dos grupos sociais menores." Enquanto a solidariedade impulsiona o auxílio, a subsidiariedade regula o "excesso de auxílio". "O princípio de subsidiariedade supõe os princípios da solidariedade e do bem comum, sem com eles identificar-se. A sociedade é obrigada a ajudar os indivíduos. Trata-se de um postulado claro do principio de solidariedade, que acentua a mitua união e obrigação. Cabe ao principio de subsidiariedade limitar e distribuir as competências a serem respeitadas nessa ajuda."

Existe também um principio de cooperação que, em matéria de Doutrina Social da Igreja serve de orientação para a atuação conjunta do Estado e da Igreja em tarefas comuns a ambos. A cooperação se refere à competência comum da Igreja e do Estado em prol do bem comum. O Concílio Vaticano II enuncia da seguinte forma este princípio: "A comunidade política e a Igreja são independentes entre si e autônomas. Ambas, porém, embora por títulos diferentes, estão a serviço da vocação pessoal e social dos mesmos homens. Tanto mais eficazmente executarão para o. bem de todos estes serviços quanto melhor cultivarem entre si a sã cooperação, consideradas tambèm. as circunstâncias dos tempos e lugares, $O$ homem, pois, não está restrito apenas ì ordem temporal, mas, vivendo na história humana, conserva integralmente a sua vocação eterna" 101

Analogicamente, em matéria de direito do menor, o princípio referir-seá a deveres e garantias jurídicas que são incumbências comuns do Estado, da sociedade e da família, com relação à criança e ao adolescente.

O principio de cooperação, sob esse ponto de vista, é norma que fundamenta a atuação conjunta das diversas esferas de coletividade que gozam de

99. Joscph Cardcal Höffncr, op.cit (cit. 89), p. 36.

$100 \mathrm{Idcm}$, p. 35.

101. Constituição Gaudium et spes (Concilio Vaticano II), n. 76. 
competência comum, admitindo-se suprimento de uma em relação à outra, sem afetar as competências privativas ou exclusivas de cada uma.

O princípio da cooperação pode ser inferido da CF, art. 227 - "é dever da familia, da sociedade e do Estado assegurar à criança e ao adolescente, com prioridade absoluta,..." Também está no ECA, arts. $4^{\circ} .86$ e 88 , convocando todas as forças de mobilização social para garantir os direitos da criança e do adolescente na política de atendimento. ${ }^{102}$

O princípio de cooperação é apresentado por Mendizábal Oses como necessário para uma autêntica Política de Menores. Para ele toda a coletividade deve estar comprometida com metas de integração comunitária tendo em vista o desenvolvimento da personalidade dos menores. ${ }^{103}$ Fala expressamente do principio de cooperación educativa, ${ }^{104}$ quando desenvolve os efeitos jurídicos comuns à "família funcional" (figura similar à família substituta do ECA, constituída mediante guarda ou tutela).

Em matéria de instrução (educação profissional), por exemplo, como se dizia acima, estabeleceu a Constituição que é dever do Estado e da família (art.205, caput), e "será promovida em colaboração da sociedade (...)". Da parte do Estado, garante-se ensino fundamental obrigatório e gratuito (art. 208, I), e o acesso a ele é reconhecido como "direito público subjetivo" (art. $208, \S 1^{\circ}$ ). No entanto, a educação vai além da instrução técnica e há uma dimensão moral que é tarefa primordial dos pais, competência privativa deles.

O princípio da cooperação, portanto, segundo ora se concebe, deveria ser utilizado para regular situações em que há competência comum dos círculos sociais, mantendo-se a precedência de um deles em relação aos demais. Nessas matérias, de competência concorrente, poderá o Estado atuar mediante órgãos não jurisdicionais. Isto se verificará na atuação do Conselho Tutelar (ECA, art. 131), por exemplo, órgão não-jurisdicional que interfere na administração do poder familiar para garantir que os direitos da criança e do adolescente sejam respeitados, sem se envolver em matérias

102. ECA, art, 86: "a politica de atendimento dos direitos da criança e do adolescente far-se-á através de um conjunto articulado de açōes governamentais e não governamentais, da União. dos Estados, do Distrito Federal e dos Municipios" (grifos nossos). O art. 88, $\mathrm{cm}$ seus diversos incisos sobre as dirctrizes da política de atendimento dos menores aponta, cntre outras: a municipalizaçào do atendimento (I), a criação dos conselhos de dircitos nas csferas federal c cstadual, bem como do Conselho Tutelar no âmbito municipal, que trabalharão articulados com a sociedade civil na própria composição desses órgàos (II), a descentralização político-administrativa na críação c manutenção de programas de atendimento cspecíficos (III), a previsão de fundos nas trĉs csfcras, ligados aos conselhos respectivos (IV), a integraçao do Judiciário. Ministério Público. Defensoria e Segurança Públicas c da Assistência Social a se dar preferencialmente pela reduçào desses órgãos a um mesmo recinto, para facilitar o tratamento integral que deve ser dado ao menor $(V)$ c também a mobilização da opinião pública para sensibilizar todos os setores da socicdade a se engajarem nesse movimento (VI). Tais disposições bem podem ser compreendidas como cstando sob inspiração do princípio da coopcração.

103. L. Mendizábal Oses, Derecho de Menores. Teoria general, Madrid, Pirâmide, 1977, p. 49.

104. Idem, p. 225. 
que são de competência exclusiva ou privativa dos pais. Quando for caso de interferência grave em matérias de competência exclusiva ou privativa dos pais, será necessário recorrer aos órgãos jurisdicionais.

2.7. Princípio da autonomia familiar e princípio da prioridade absoluta.

No jogo de competências entre os agrupamentos, em matéria de direitos da criança e do adolescente, quatro princípios basilares (todos sob a égide do princípio maior da dignidade humana) orientam o exercício da autoridade sobre o menor. São eles: principio da prioridade absoluta dos direitos da criança e do adolescente, princípio da autonomia familiar, princípio da cooperação e princípio da subsidiariedade.

Enquanto os pais respeitam os direitos fundamentais dos filhos sob sua tutela, o princípio da autonomia familiar garante-lhes liberdade de exercício dos poderes inerentes ao poder familiar. Neste caso, devem o Estado e a sociedade auxiliar no que for necessário para o bom desempenho de suas funções, atualizando-se o princípio da cooperação.

Quando houver desrespeito aos direitos da criança e do adolescente, em desrespeito à prioridade absoluta dos direitos fundamentais da criança e do adolescente, o princípio da autonomia familiar perde força, conjunturalmente, e o Estado e a sociedade civil devem tomar providências, de acordo com o princípio da subsidiariedade. A aplicação deste principio pode resultar em colaboração com os pais em matérias de sua competência exclusiva, ou privativa, quando tal colaboração for suficiente para corrigir o desvio, ou pode chegar até mesmo à inibição total do poder familiar (decretando-se sua perda), com a finalidade de garantir os direitos e a formaçĩo da criança ou adolescente.

São dois princípios de ordem material, isto é, visando à tutela dos direitos fundamentais dos filhos (prioridade absoluta) ou dos pais no exercício do poder familiar (autonomia familiar), e dois princípios de ordem procedimental, que têm por escopo determinar o grau de intervenção das demais esferas de coletividade no âmbito familiar, para proteger a criança e o adolescente (cooperação e subsidiariedade).

O principio da autonomia familiar pode ser reconhecido como integrante do sistema normativo brasileiro, analisando-se os dispositivos que reconlecem aos pais o direito de exercer o poder familiar sobre a prole, e perpassa todas as normas que tratam da competência dos pais em sua gestão (especialmente: CF, art. 229; CC, arts.1.630, 1.634, 1.689; ECA, arts.19, 21 e 22).

Os genitores têm precedência na ordem de entidades responsáveis pelo bem estar do menor, e não mais uma presença imune a qualquer interferência. A autonomia familiar não é um princípio absoluto. ${ }^{105}$ Evita-se, dessa forma, que tal

105. A atcnuação do princípio da autonomia familiar, tido como dogma que protcgia o cxcrcício absoluto do poder familiar, ć obra da scgunda metade do sćculo XX, como afirma Paolo Zatti, cm "Rapporto educativo e intervento del gindice", L'autonomia dei minori tra famiglia e societì. Milano, Giuftic̀, 1980, pp. $185-317$. 
princípio possa servir como argumento para encobrir abusos no exercício do poder familiar, sendo invocado em detrimento da criança ou adolescente a ele sujeito.

Hoje, quando a prioridade absoluta da criança e do adolescente é princípio básico de todo o sistema jurídico, a autonomia familiar prevalece enquanto no seio familiar se respeitam os seus direitos fundamentais. Também nestes casos de pode invocar a $\mathrm{CF}$, art. $226, \S 8^{\circ}$, pelo qual se garante proteção à família na pessoa de cada um de seus membros.

Para lançar mão do uso desses princípios deve-se analisar cada caso, verificando, em primeiro lugar, se os direitos fundamentais dos menores estão sendo ameaçados ou desrespeitados, para que haja legitimidade de auxílio dos poderes públicos e de entidades não-governamentais. De acordo com a situação concreta, será caso de aplicar-se o princípio da subsidiariedade ou o princípio de cooperação. ${ }^{100}$

Em situações relacionadas à falta de atenção moral da criança, de acordo com o potencial danoso da ação ou omissão dos pais à personalidade do fillho, pode-se chegar à decretação da suspensão ou perda do poder familiar, respaldadas no princípio de subsidiariedade, que leva à substituição da autoridade legitimada inicialmente para administrá-lo. Neste caso, o princípio da subsidiariedade e o da prioridade absoluta estarão fundamentando a decisão judicial remotamente.

São Paulo, junho de 2002

106. Aplicação do princípio da cooperação pode ser percebido, por cxemplo, no dispositivo do ECA que cstabclecc (art.23, $\$$ único) que cm caso de carência de recursos, sendo cstc o único motivo que ameaça ou impede que scja regular o excrcicio do poder familiar, a familia "deverá obrigatoriamente ser. incluida em programas oficiais de auxilio". Trata-se aqui de competência comum suplementar do Estaklo c socicdado civil. 